\title{
The Discovery and Character of Pleistocene Calcrete Uranium Deposits in the Southern High Plains of West Texas, United States
}

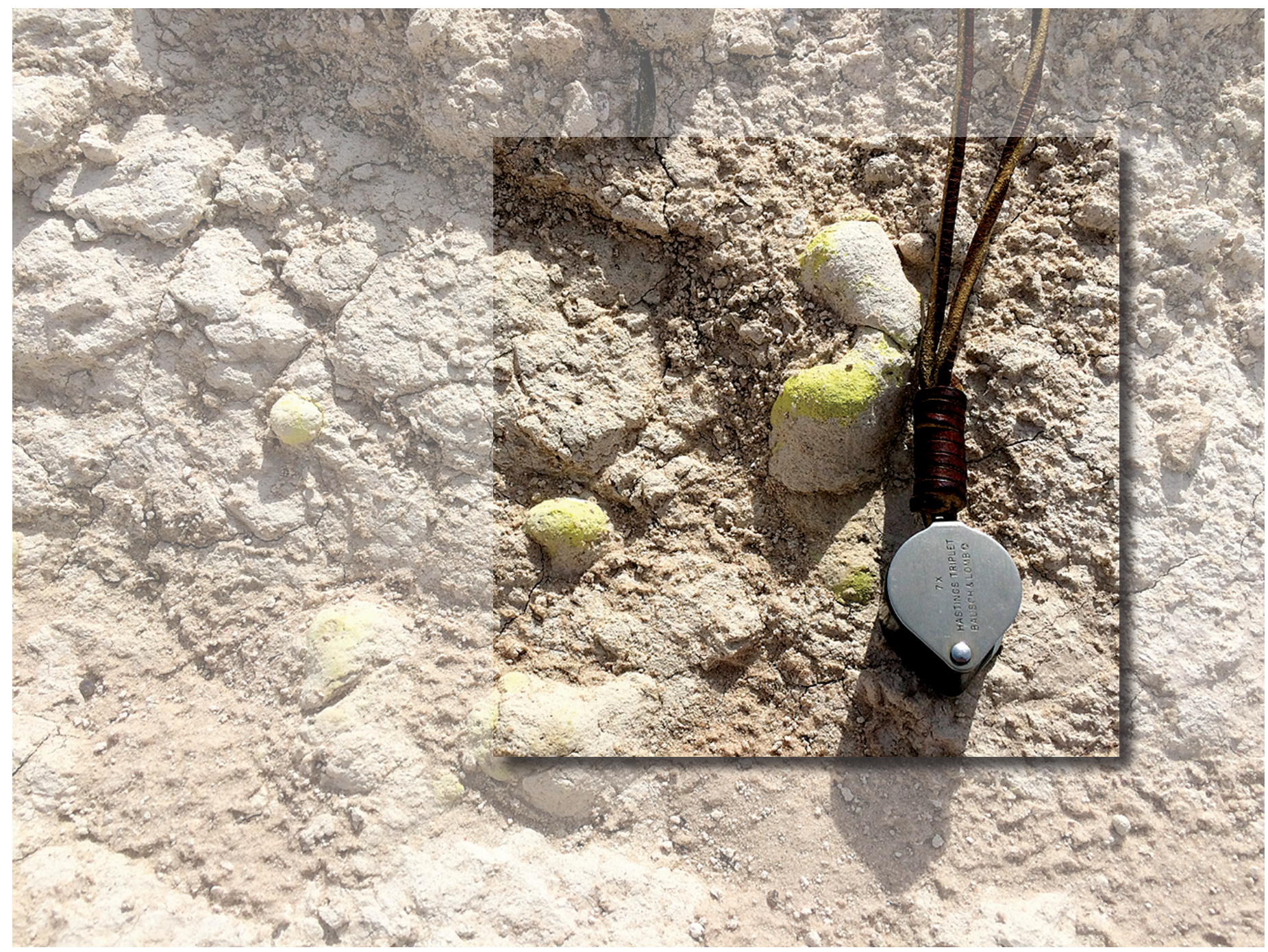

Scientific Investigations Report 2017-5134 
Cover. Uranium mineralization (yellow) in calcrete sedimentary rocks at the Sulphur Springs Draw uranium deposit, Martin County, west Texas. 


\section{The Discovery and Character of Pleistocene Calcrete Uranium Deposits in the Southern High Plains of West Texas, United States}

By Bradley S. Van Gosen and Susan M. Hall

Scientific Investigations Report 2017-5134 


\title{
U.S. Department of the Interior \\ RYAN K. ZINKE, Secretary
}

\section{U.S. Geological Survey William H. Werkheiser, Deputy Director exercising the authority of the Director}

\author{
U.S. Geological Survey, Reston, Virginia: 2017
}

For more information on the USGS - the Federal source for science about the Earth, its natural and living resources, natural hazards, and the environment-visit https://www.usgs.gov or call 1-888-ASK-USGS.

For an overview of USGS information products, including maps, imagery, and publications, visit https://store.usgs.gov.

Any use of trade, firm, or product names is for descriptive purposes only and does not imply endorsement by the U.S. Government.

Although this information product, for the most part, is in the public domain, it also may contain copyrighted materials as noted in the text. Permission to reproduce copyrighted items must be secured from the copyright owner.

Suggested citation:

Van Gosen, B.S., and Hall, S.M., 2017, The discovery and character of Pleistocene calcrete uranium deposits in the Southern High Plains of west Texas, United States: U.S. Geological Survey Scientific Investigations Report 2017-5134, 27 p., https://doi.org/10.3133/sir20175134.

ISSN 2328-0328 (online) 


\section{Acknowledgments}

The authors are very grateful to Clyde Yancey of UEC (Uranium Energy Corporation) for allowing us to examine and publish information from the archived records of Kerr-McGee Corporation's exploration project in the Southern High Plains. We thank Mark Hannon, formerly U.S. Geological Survey (USGS), for scanning and georectifying maps and plates from the Kerr-McGee collection for our use. James Paces, research geologist with the USGS, contributed uranium-series isotope analyses of uranium minerals in outcrop samples collected from the Sulphur Springs Draw deposit. William Benzel, physical scientist with the USGS, provided X-ray diffraction analyses of mineral samples. Rusty Winn, geologist for R.E. Janes Gravel Company, graciously gained us access to areas of uranium mineralization in Yellow House Canyon and collected samples on our behalf. We appreciate the constructive reviews of the manuscript by Robert Zielinski, retired emeritus USGS geologist, and Rusty Winn.

\section{Contents}

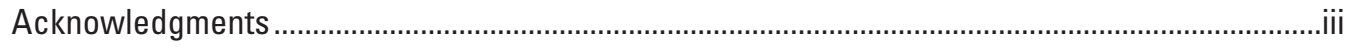

Abstract

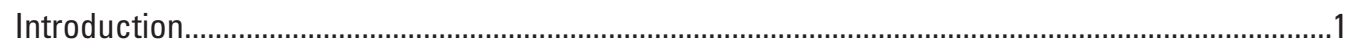

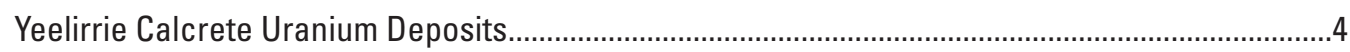

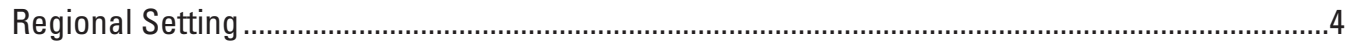

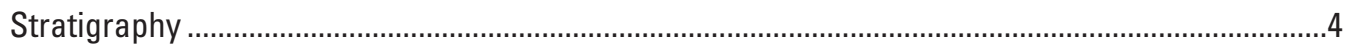

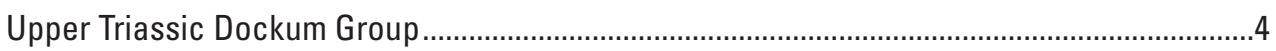

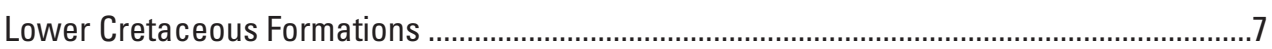

Miocene-Pliocene Ogallala Formation......................................................................................

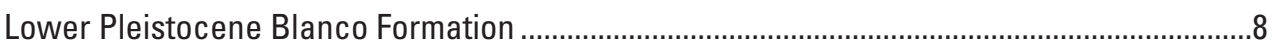

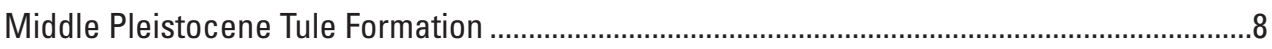

Upper Pleistocene Tahoka Formation ..........................................................................................

Pleistocene Lacustrine Deposits that Host the Uranium Deposits .............................................

Quaternary Blackwater Draw Formation and Holocene Sediments..........................................

Kerr-McGee Corporation's Exploration Program and Discoveries in the Southern High Plains....10

Early Exploration for Triassic Red-Bed Uranium Deposits..................................................10

Exploration Program Transition to Yeelirrie Uranium Deposits .................................................10

The Discovery of Uranium Deposits ................................................................................12

Sulphur Springs Draw Deposit ...................................................................................12

U.S. Geological Survey Sampling Results from the Sulphur Springs Draw

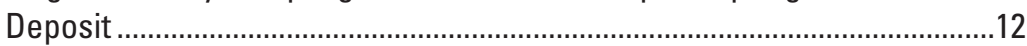

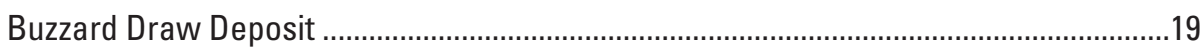

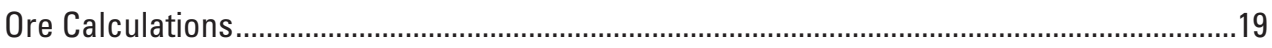

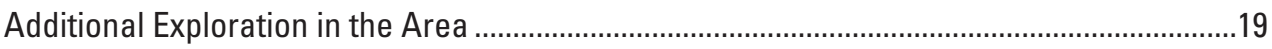

Kerr-McGee Corporation's Cost-of-Production Analysis...................................................19

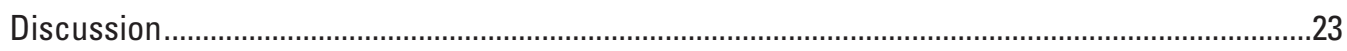

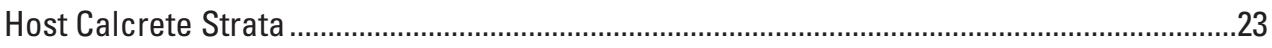

Sources and Mechanisms of the Uranium-Vanadium Mineralization...................................22

Relative Ages of the Uranium-Vanadium Mineralization .......................................................24

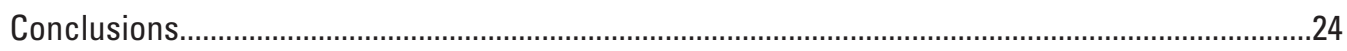

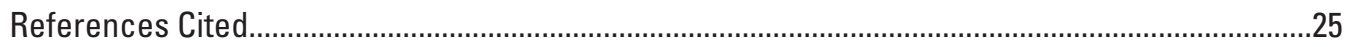




\section{Figures}

1. Index map of the Southern High Plains province showing the location of two uranium deposits discovered in the southeast part of the region: the Sulphur Springs Draw and Buzzard Draw deposits.

2. Map showing the location of the Sulphur Springs Draw and Buzzard Draw uranium deposits discovered by Kerr-McGee Corporation in the mid-1970s

3. Generalized geologic map of the southeastern area of the Southern High Plains in west Texas

4. Stratigraphy of the geologic units exposed in the Southern High Plains province showing the units relevant to the geologic setting of the uranium deposits.

5. Examples of the yellow and greenish-yellow uranium mineralization exposed in a trench near the western edge of the Sulphur Springs Draw deposit.

6. Drill-hole locations of Kerr-McGee Corporation's exploratory drilling of the Sulphur Springs Draw deposit.

7. Cross section of the Sulphur Springs Draw deposit based on drilling results, showing lithologies and down-hole gamma-ray measurements.

8. Index map of the Sulphur Springs Draw deposit showing the subsurface extent of the deposit based on drilling by Kerr-McGee Corporation and their interpretive map based on the drilling results.

9. Scanning electron microscope image of uranium mineralization in the Sulphur Springs Draw deposit. 18

10. Drill-hole locations of Kerr-McGee Corporation's exploratory drilling of the Buzzard Draw deposit.

11. Index map of the Buzzard Draw deposit showing the subsurface extent of the deposit based on drilling by Kerr-McGee Corporation.

12. Drill-hole locations of Kerr-McGee Corporation's 1970s exploratory drilling program in the Southern High Plains region of Texas

\section{Tables}

1. Reported ore tonnages and grades in the Sulphur Springs Draw and Buzzard Draw uranium deposits, west Texas

2. Concentrations of selected elements in samples collected in 2014 and 2015 from outcrops within the general area in which 1970s reconnaissance airborne radiometric surveys detected radiometric anomalies

3. Concentrations of selected elements in samples collected in 2015 by this study from outcrops near the western edge of the Sulphur Springs Draw deposit, Martin County, Texas 


\section{Conversion Factors}

U.S. customary units to International System of Units

\begin{tabular}{lcl}
\hline \multicolumn{1}{c}{ Multiply } & By & \multicolumn{1}{c}{ To obtain } \\
\hline foot (ft) & Length & \\
mile (mi) & 0.3048 & meter $(\mathrm{m})$ \\
\hline \multicolumn{3}{l}{ kilometer $(\mathrm{km})$} \\
\hline acre-foot (acre- $\mathrm{ft})$ & 1.609 & \\
acre-foot (acre-ft) & Volume & cubic meter $\left(\mathrm{m}^{3}\right)$ \\
\hline & 1,233 & cubic hectometer $\left(\mathrm{hm}^{3}\right)$ \\
\hline pound, avoirdupois $(\mathrm{lb})$ & 0.001233 & \\
ton, short $(2,000 \mathrm{lb})$ & Mass & kilogram $(\mathrm{kg})$ \\
\hline & 0.4536 & metric ton $(\mathrm{t})$ \\
\hline cubic foot per short ton $\left(\mathrm{ft}^{3 / \mathrm{short} \text { ton }}\right)$ & 0.9072 & \\
\hline
\end{tabular}

International System of Units to U.S. customary units

\begin{tabular}{|c|c|c|}
\hline Multiply & By & To obtain \\
\hline \multicolumn{3}{|c|}{ Length } \\
\hline centimeter $(\mathrm{cm})$ & 0.3937 & inch (in.) \\
\hline meter $(\mathrm{m})$ & 3.281 & foot $(\mathrm{ft})$ \\
\hline meter $(\mathrm{m})$ & 1.094 & yard (yd) \\
\hline kilometer $(\mathrm{km})$ & 0.6214 & mile (mi) \\
\hline kilometer (km) & 0.5400 & mile, nautical (nmi) \\
\hline \multicolumn{3}{|c|}{ Mass } \\
\hline metric ton $(\mathrm{t})$ & 1.102 & ton, short $[2,000 \mathrm{lb}]$ \\
\hline metric ton $(\mathrm{t})$ & 0.9842 & ton, long [2,240 lb] \\
\hline \multicolumn{3}{|c|}{ Concentration } \\
\hline microgram per liter $(\mu \mathrm{g} / \mathrm{L})$ & $1.0432 \times 10^{-9}$ & ounce per fluid ounce (oz/fl. oz) \\
\hline
\end{tabular}

\section{Supplemental Information}

Concentrations of chemical constituents in water are given in either milligrams per liter (mg/L) or micrograms per liter $(\mu \mathrm{g} / \mathrm{L})$. Results for measurements of stable isotopes of an element (with symbol E) in water, solids, and dissolved constituents commonly are expressed as the relative difference in the ratio of the number of the less abundant isotope (i $E$ ) to the number of the more abundant isotope of a sample with respect to a measurement standard. 


\section{Abbreviations}

\begin{tabular}{|c|c|}
\hline $\mathrm{Al}$ & aluminum \\
\hline${ }^{40} \mathrm{Ar} /{ }^{39} \mathrm{Ar}$ & argon-argon radiometric dating method \\
\hline As & arsenic \\
\hline $\mathrm{Ba}$ & barium \\
\hline${ }^{14} \mathrm{C}$ & carbon-14 isotope \\
\hline $\mathrm{Ca}$ & calcium \\
\hline $\mathrm{Cu}$ & copper \\
\hline DOD & U.S. Department of Defense \\
\hline EDS & energy-dispersive X-ray spectroscopy \\
\hline EPA & U.S. Environmental Protection Agency \\
\hline $\mathrm{Fe}$ & iron \\
\hline $\mathrm{H}_{2} \mathrm{O}$ & water \\
\hline K & potassium \\
\hline ka & kilo-annum (thousand years ago) \\
\hline $\mathrm{Li}$ & lithium \\
\hline $\mathrm{Mg}$ & magnesium \\
\hline $\mathrm{Mn}$ & manganese \\
\hline Mo & molybdenum \\
\hline Mt & million metric tons \\
\hline$P$ & phosphorus \\
\hline $\mathrm{Pb}$ & lead \\
\hline ppm & parts per million \\
\hline SEM & scanning electron microscope \\
\hline $\mathrm{Sr}$ & strontium \\
\hline Th & thorium \\
\hline U & uranium \\
\hline $\mathrm{U}_{3} \mathrm{O}_{8}$ & uranium oxide \\
\hline USGS & U.S. Geological Survey \\
\hline V & vanadium \\
\hline$w t \%$ & weight percent \\
\hline $\mathrm{Zn}$ & zinc \\
\hline $\mathrm{Zr}$ & zirconium \\
\hline
\end{tabular}




\title{
The Discovery and Character of Pleistocene Calcrete Uranium Deposits in the Southern High Plains of West Texas, United States
}

\author{
By Bradley S. Van Gosen and Susan M. Hall
}

\section{Abstract}

This report describes the discovery and geology of two near-surface uranium deposits within calcareous lacustrine strata of Pleistocene age in west Texas, United States. Calcrete uranium deposits have not been previously reported in the United States. The west Texas uranium deposits share characteristics with some calcrete uranium deposits in Western Australia - uranium-vanadium minerals hosted by nonpedogenic calcretes deposited in saline lacustrine environments.

In the mid-1970s, Kerr-McGee Corporation conducted a regional uranium exploration program in the Southern High Plains province of the United States, which led to the discovery of two shallow uranium deposits (that were not publicly reported). With extensive drilling, Kerr-McGee delineated one deposit of about 2.1 million metric tons of ore with an average grade of 0.037 percent $\mathrm{U}_{3} \mathrm{O}_{8}$ and another deposit of about 0.93 million metric tons of ore averaging 0.047 percent $\mathrm{U}_{3} \mathrm{O}_{8}$.

The west-Texas calcrete uranium-vanadium deposits occur in calcareous, fine-grained sediments interpreted to be deposited in saline lakes formed during dry interglacial periods of the Pleistocene. The lakes were associated with drainages upstream of a large Pleistocene lake. Age determinations of tephra in strata adjacent to one deposit indicate the host strata is middle Pleistocene in age.

Examination of the uranium-vanadium mineralization by scanning-electron microscopy indicated at least two generations of uranium-vanadium deposition in the lacustrine strata identified as carnotite and a strontium-uraniumvanadium mineral. Preliminary uranium-series results indicate a two-component system in the host calcrete, with early lacustrine carbonate that was deposited (or recrystallized) about 190 kilo-annum, followed much later by carnotite-rich crusts and strontium-uranium-vanadium mineralization in the Holocene (about 5 kilo-annum). Differences in initial ${ }^{234} \mathrm{U} /{ }^{238} \mathrm{U}$ activity ratios indicate two separate, distinct fluid sources.

\section{Introduction}

In the mid-1970s, Kerr-McGee Corporation (hereafter Kerr-McGee) conducted a regional uranium exploration program in the Southern High Plains province of the United States (fig. 1). Its extensive exploration and drilling project led to the discovery and detailed delineation of two near-surface uranium deposits within Pleistocene-age strata of calcareous saline lake sediments. These uranium deposits are located near Big Spring, Texas: the Buzzard Draw deposit is about 25 kilometers $(\mathrm{km})$ to the north-northwest, and the Sulphur Springs Draw deposit is $50 \mathrm{~km}$ to the northwest (fig. 2). The deposits were found within privately owned lands (and remain so) and were explored and drilled through lease agreements. Based on more than 900 total drill holes in both deposits, the Sulphur Springs Draw deposit was estimated to contain about 2.1 million metric tons $(\mathrm{Mt})$ of ore with an average grade of 0.037 percent $\mathrm{U}_{3} \mathrm{O}_{8}$ and the Buzzard Draw deposit about $0.93 \mathrm{Mt}$ of ore averaging 0.047 percent $\mathrm{U}_{3} \mathrm{O}_{8}$ (table 1; data from Kerr-McGee internal company memorandum).

In 1981, Kerr-McGee conducted an economic analysis to estimate the total costs of developing the two deposits, from mining, transportation, and milling costs through the production of yellowcake (milled uranium oxide). The shallow depth of the deposits, covered by no more than 20 meters (m) of unmineralized rock (overburden), and the soluble nature of the deposits (hosted in calcrete) made them potentially attractive for small-scale open-pit mining. However, the results of the complete economic analysis indicated marginal profitability in an uncertain uranium market, which dissuaded Kerr-McGee from developing these deposits. Its exploration program in this region ended soon after and they released no information on the discoveries and the nature of these deposits was not reported in the published literature.

By the time Kerr-McGee ceased operations for uranium exploration in this region, it had compiled a substantial collection of records from its exploration and drilling 


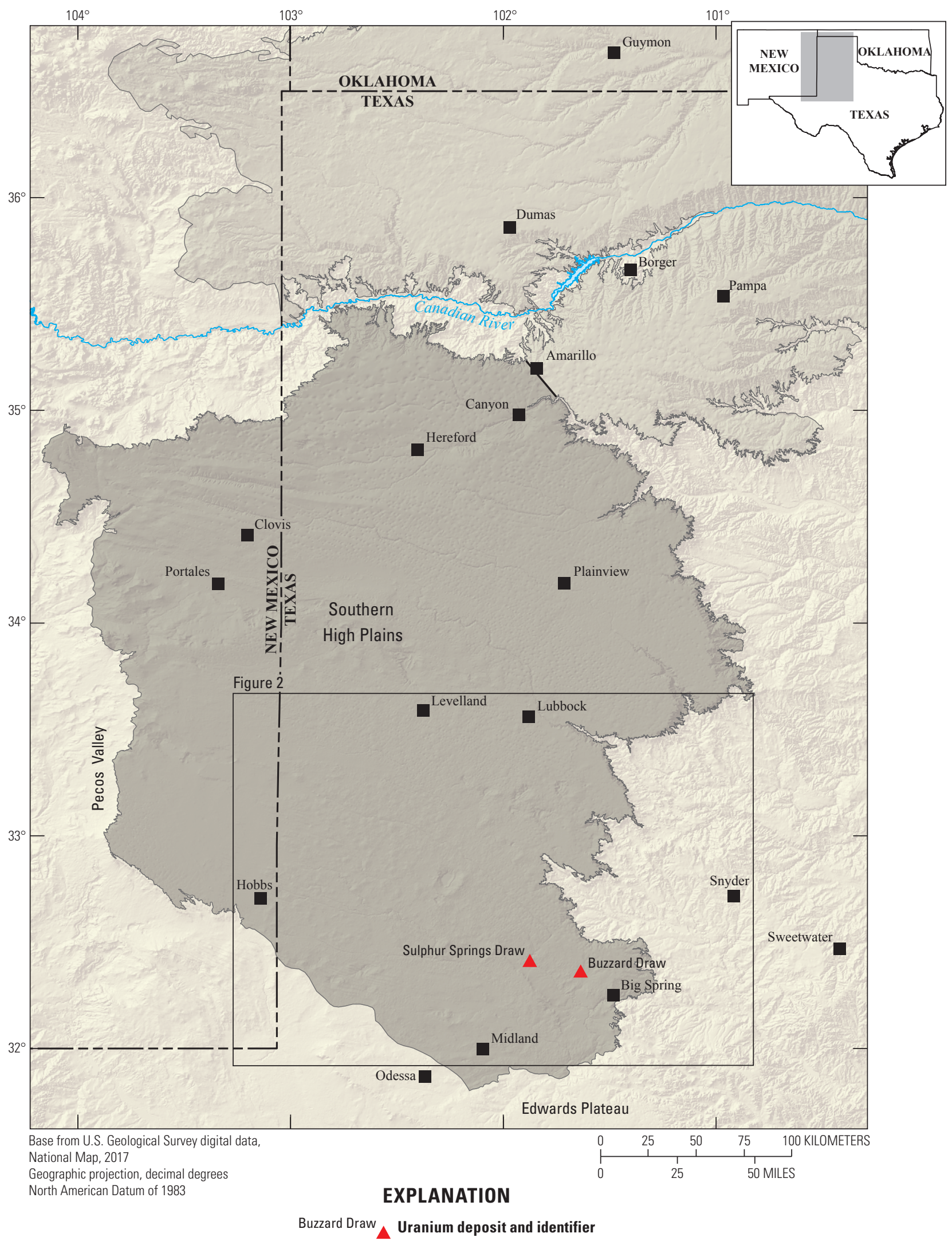

Figure 1. Index map of the Southern High Plains province showing the location of two uranium deposits discovered in the southeast part of the region: the Sulphur Springs Draw and Buzzard Draw deposits. 


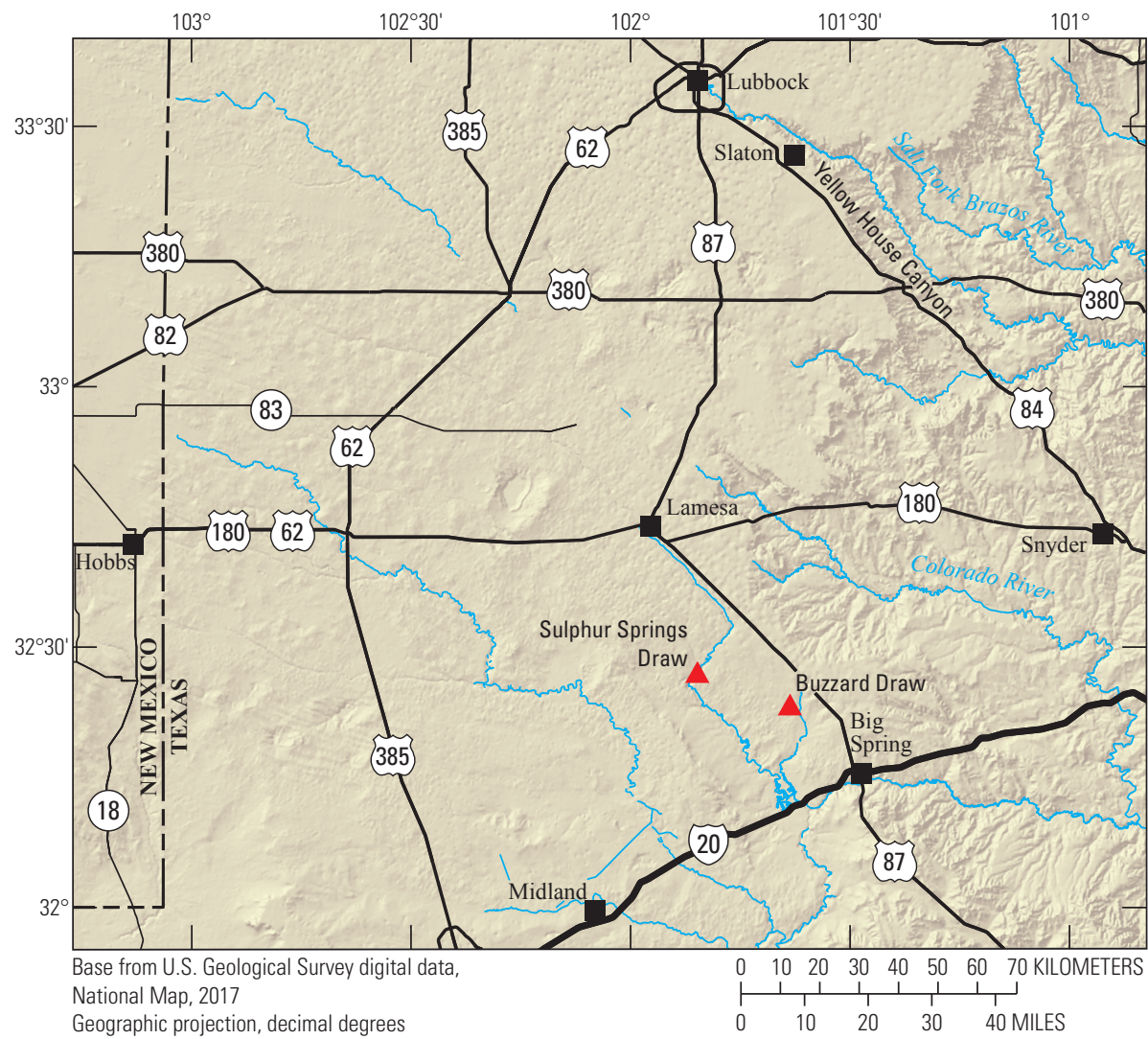

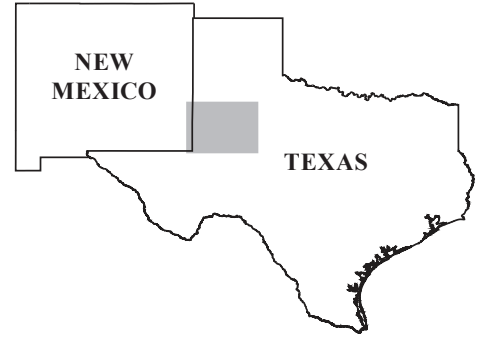

\section{EXPLANATION}

Buzzard Draw Uranium deposit and identifier

Figure 2. Map showing the location of the Sulphur Springs Draw and Buzzard Draw uranium deposits discovered by Kerr-McGee Corporation in the mid-1970s.

Table 1. Reported ore tonnages and grades in the Sulphur Springs Draw and Buzzard Draw uranium deposits, west Texas, as stated in a Kerr-McGee Corporation company memorandum dated February 25, 1981.

[ 1 short ton $=0.9072$ metric tons; 1 foot $(\mathrm{ft})=0.3048$ meters. Multiply $\mathrm{U}_{3} \mathrm{O}_{8}$ percent by 0.8480 to obtain uranium percent.]

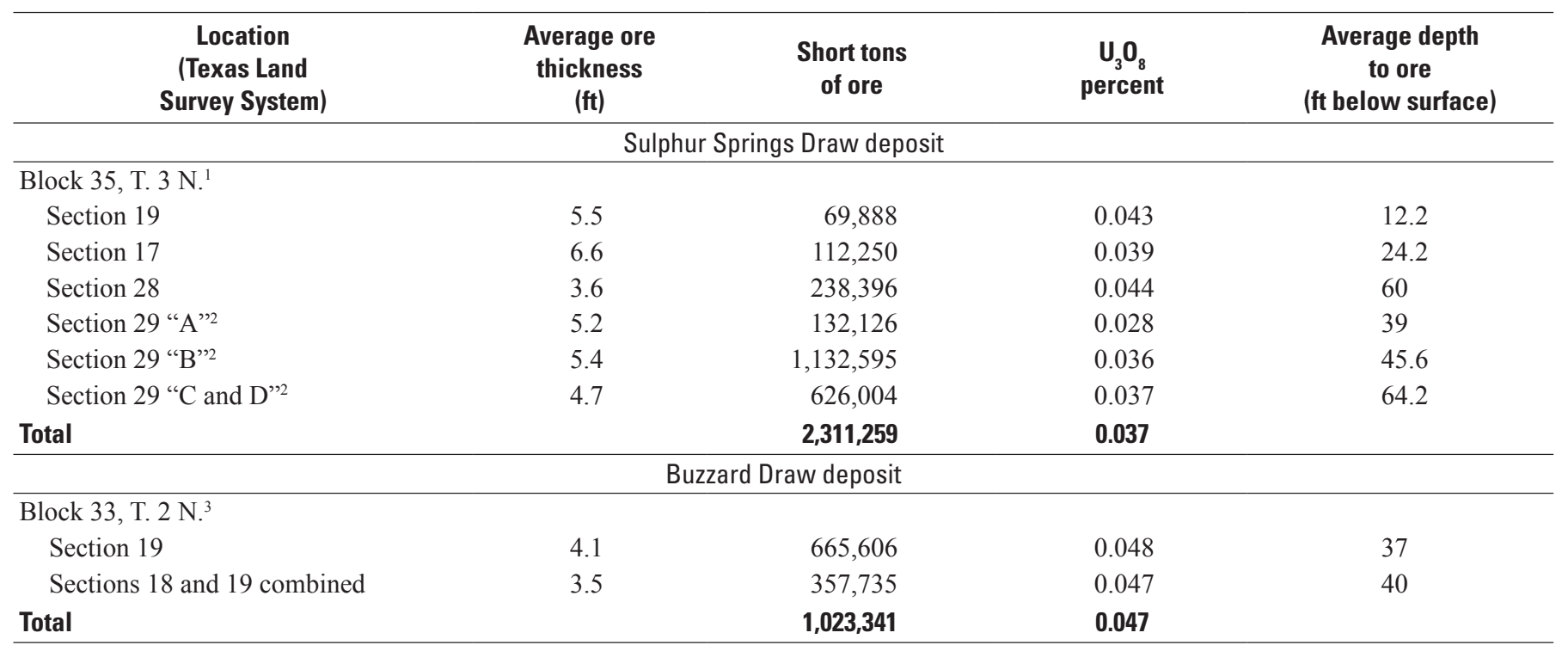

${ }^{1}$ Approximate center of the deposit is in Section 29 at lat $32.4481^{\circ} \mathrm{N}$., long $101.8608^{\circ} \mathrm{W}$.

${ }^{2}$ The "A," "B," and "C and D" designations for Section 29 refer to vertically stacked ore horizons.

${ }^{3}$ Approximate center of the deposit is in Section 19 at lat $32.3972^{\circ} \mathrm{N}$., long $101.6333^{\circ} \mathrm{W}$. 
program in the Southern High Plains region, including company memoranda, reports, maps, cross sections, and drill-hole lithology and gamma-ray logs. These records were later purchased by Uranium Energy Corporation (UEC), who has maintained the files. In 2015, UEC allowed the U.S. Geological Survey (USGS) to view these files and gave permission to photocopy, scan, and publish selected information. In addition to a review of the Kerr-McGee findings, this report provides additional observations of the geologic setting and mineralogy of the deposits, preliminary estimates of the age range of the deposits, and additional discussion of possible geologic and geochemical factors and mechanisms that led to their formation.

\section{Yeelirrie Calcrete Uranium Deposits}

Kerr-McGee focused its 1970s uranium exploration program on the Southern High Plains (fig. 1) because it determined that the region's geology, paleogeography, and paleoclimate was similar to the setting of the Yeelirrie deposits, which are large, calcrete uranium deposits that had been recently discovered, in 1972, in a remote area of Western Australia. The Yeelirrie deposits are uraniferous calcrete occurrences hosted by nonpedogenic calcretes and dolocretes deposited in valleys as delta and lacustrine sediments that formed in arid inland regions with low relief (Carlisle, 1978; Butt and others, 1984; Cameron, 1984; Cavaney, 1984; Heath and others, 1984). The primary uranium mineral in the Yeelirrie deposits is carnotite, a potassium-uranium-vanadium mineral $\left(\mathrm{K}_{2}\left(\mathrm{UO}_{2}\right)_{2}\left(\mathrm{VO}_{4}\right)_{2} \cdot 3 \mathrm{H}_{2} \mathrm{O}\right)$. The Yeelirrie deposits contain disseminated carnotite hosted by lenticular masses of alluvium and soil cemented by calcium (calcrete) or calciummagnesium carbonate (dolocrete). The carnotite-bearing layers can be as much as $7 \mathrm{~m}$ thick, and usually occur within $20 \mathrm{~m}$ of the surface (Carlisle, 1978).

It is important to emphasize that the sheet-like layers of carbonate in the topmost few meters of the Southern High Plains, regionally referred to as "caliche," are related to pedogenic (soil-forming) processes (Reeves, 1976; Holliday, 1989, 1990; Gustavson and others, 1995; Gustavson, 1996).

(Although caliche is now more commonly referred to as "soil carbonate" or "pedogenic carbonate" by soil scientists, the term "caliche" is used in this report to follow the common usage in the literature focusing on this region.) Saline lacustrine basins that formed in the Pleistocene and still exist today are scattered across the Southern High Plains, and these often contain lenticular deposits of calcareous, nonpedogenic sediments (calcrete) formed by evaporation of saline lakes (Evans, 1956; Frye and Leonard, 1957, 1968).

\section{Regional Setting}

The previously unreported calcrete uranium deposits of west Texas, United States, lie in the southeast part of the Southern High Plains physiographic province (fig. 1). The Southern High Plains, also referred to as the "Llano Estacado" or "Staked Plains" (for example, Frye and others, 1982), generally coincides with the erosional extent of the Ogallala Formation and includes roughly the northern half of the Permian Midland Basin. The province is bounded by caprock escarpments to the east and west and by the Canadian River to the north; to the south, it grades into the Edwards Plateau (fig. 1). Most of the Southern High Plains province is in northwest Texas, but it extends into southeast New Mexico on its western side (Reeves, 1972; Frye and others, 1982). The dominant cap rock in this region is a thick layer of caliche, as much as $5 \mathrm{~m}$ thick.

\section{Stratigraphy}

Rocks exposed in the Southern High Plains are predominantly flat-lying, Upper Triassic to Holocene sedimentary strata (figs. 3 and 4). The two discovered uranium deposits occur within weakly consolidated, calcareous sediments that were deposited in saline lake environments during the late Pleistocene. The stratigraphy of the Southern High Plains provides insights into the paleogeographic setting and environmental conditions that contributed to the formation of these uncommon uranium deposits.

\section{Upper Triassic Dockum Group}

The Dockum Group in the southeastern part of the Southern High Plains is typified by alternating brownish-red and greenish-gray strata of cross-bedded sandstone, clay, sandy to silty shale, and conglomerate (Eifler and others, 1974; McGowen and others, 1979; Frelier, 1987; May, 1988; Murry, 1989). The basal unit is a conglomerate containing chert pebbles, sandstone cobbles, and petrified wood. The Dockum Group has a maximum thickness of about $137 \mathrm{~m}$ in the province. The Dockum Group strata represent deposition in fluvial, lacustrine, lacustrine-deltaic, lacustrine-beach, valley-fill environments and paleosols; fluvial deposits are most abundant (McGowen and others, 1979; May, 1988).

Scattered areas within the Dockum Group in west Texas exhibit anomalous radioactivity, 2 to 5 times higher than background, mainly in grayish and greenish strata and in carbonaceous material (Finch, 1975). In the Trujillo Formation, the uppermost formation of the Dockum Group, scattered 


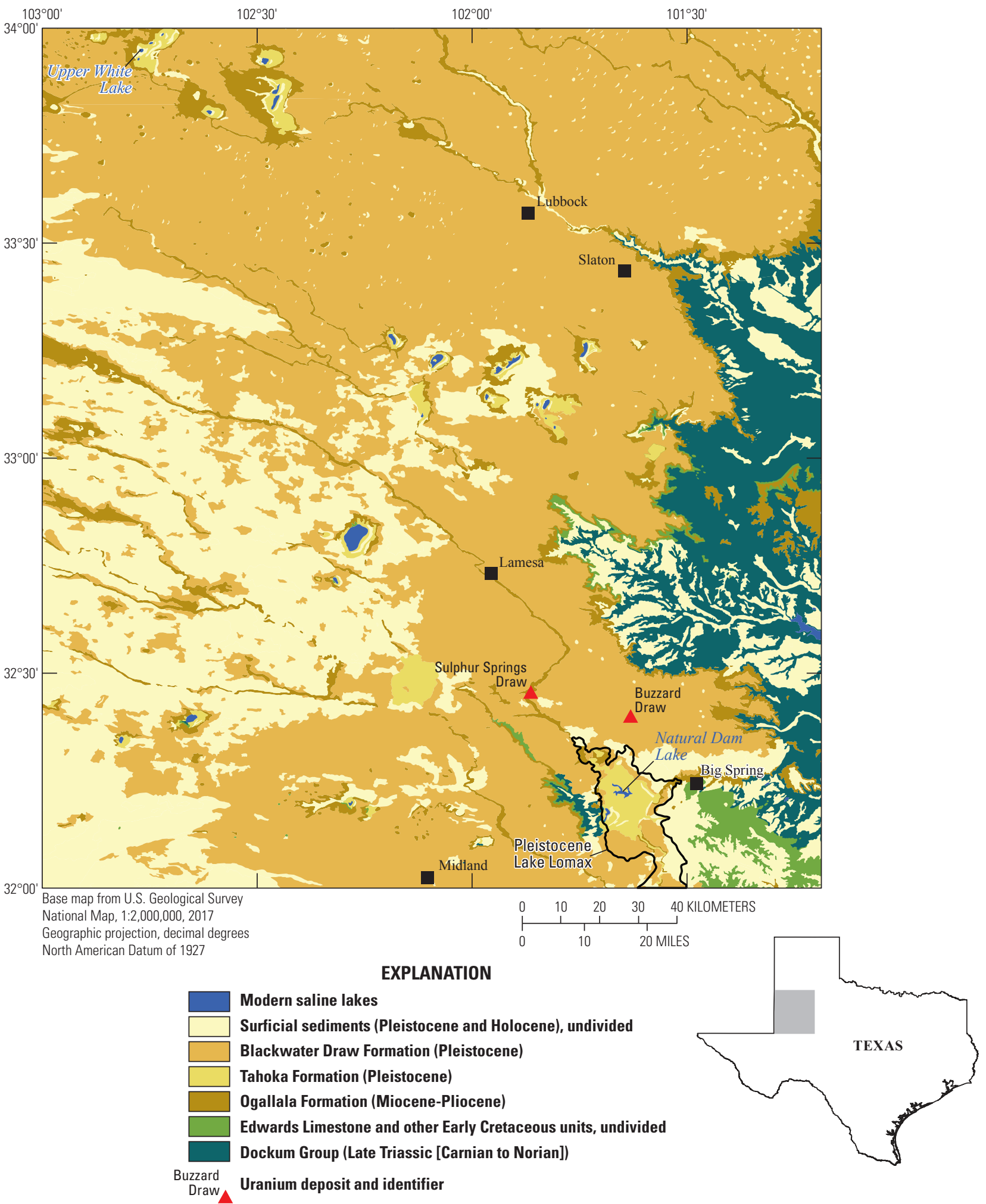

Figure 3. Generalized geologic map of the southeastern area of the Southern High Plains in west Texas. Geology shown is generalized from Barnes and others (1992). Outline of Lake Lomax from Frye and Leonard (1968). 


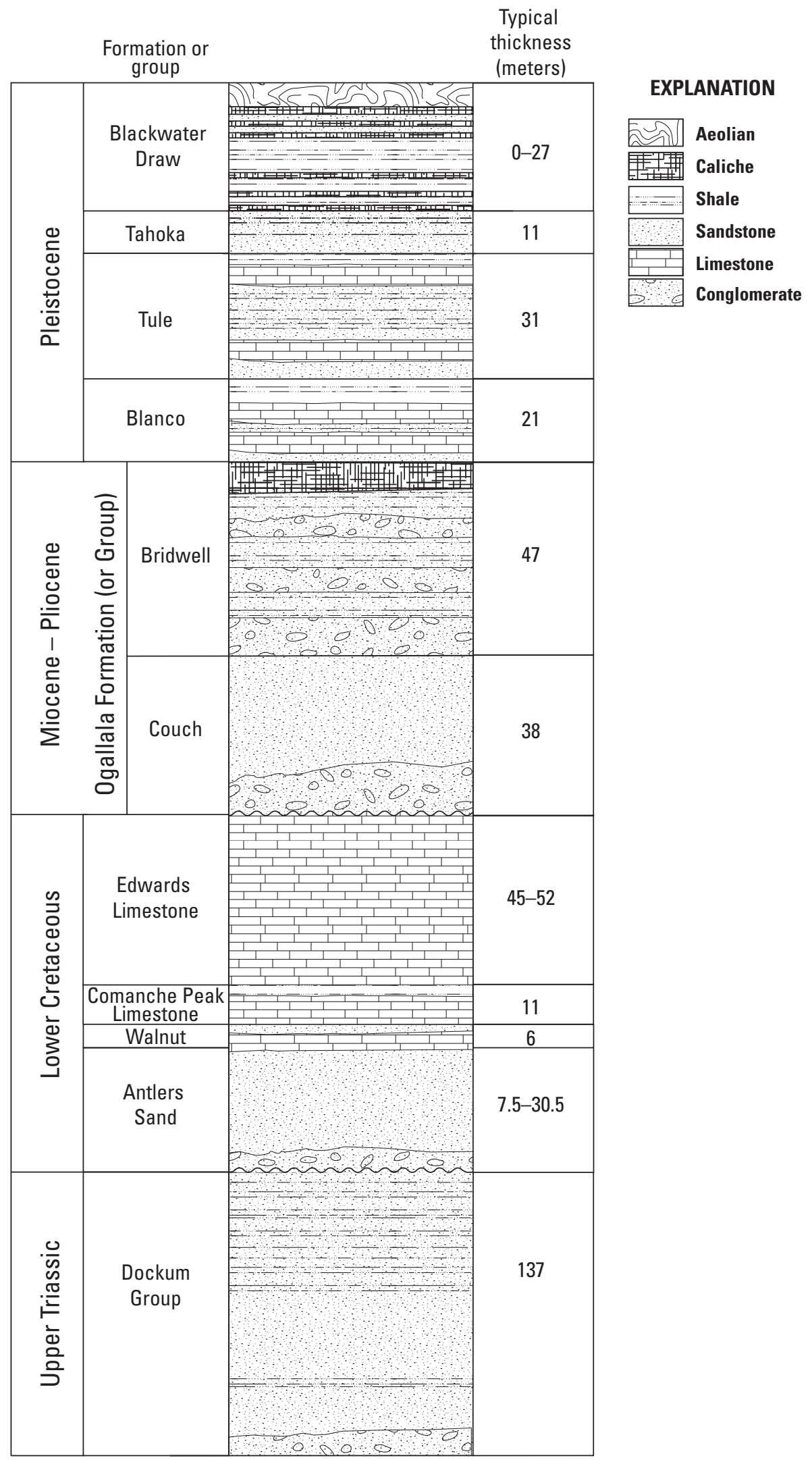

Figure 4. Stratigraphy of the geologic units exposed in the Southern High Plains province showing the units relevant to the geologic setting of the uranium deposits. Stratigraphic information from Evans (1956), Eifler and others (1974), Holliday (1989), and Murry (1989). 
lenses of uranium mineralization are no more than 30 centimeters $(\mathrm{cm})$ thick but can be up to $250 \mathrm{~m}$ long; they are found in deposits of fluvial channels. The largest identified deposit comprised about 780 short tons (708 metric tons), averaging 0.20 percent $\mathrm{U}_{3} \mathrm{O}_{8}$ (Finch, 1975). Uranium minerals reported are tyuyamunite, metatyuyamunite, autinite, meta-autunite, bayleyite, liebigite, and cuprosklodowskite (Finch, 1975).

To evaluate the uranium-bearing potential of the Dockum Group, McGowen and others (1977) collected and analyzed the uranium content of more than 400 outcrop samples of the different depositional facies. The majority of their samples were collected in the extensive outcrops of the Dockum Group that are east of the caprock escarpment that extends from the Big Spring region to the Slaton region (fig. 3). About 90 percent of their Dockum samples contained less than 5 parts per million $(\mathrm{ppm}) \mathrm{U}_{3} \mathrm{O}_{8}$. In the fluvial facies, meandering stream deposits had the highest uranium content, mainly in channel lag deposits (high value of 79 ppm $\mathrm{U}_{3} \mathrm{O}_{8}$ in lag channel with carbonized logs). Lacustrine deposits had the highest uranium contents (with a maximum value of $840 \mathrm{ppm} \mathrm{U}_{3} \mathrm{O}_{8}$ ). McGowen and others (1977) concluded that the most favorable Dockum Group strata for uranium occurrences are fluvial, deltaic, and lacustrine facies. McGowen and others (1977, p. 67) further concluded that "one can speculate that most of the uranium that will be found in the Triassic Dockum Group of Texas will be in the channel lag facies."

It is noteworthy that the Pleistocene-age lacustrine strata hosting the two uranium-bearing calcrete deposits described in this report rests directly on the Dockum Group. This is a significant erosional unconformity and indicates that any Lower Cretaceous strata and Miocene-Pliocene Ogallala Formation strata that may have been deposited in these areas was removed prior to the development of Pleistocene lakes.

\section{Lower Cretaceous Formations}

Lower Cretaceous rocks exposed in the southern areas of the Southern High Plains include, from oldest to youngest, the Antlers Sand, Walnut Formation, Comanche Peak Limestone, and Edwards Limestone (fig. 4). More detailed descriptions of these units are provided by Eifler and others (1974), the source of the generalized descriptions of the Cretaceous formations that follow.

- The Antlers Sand consists of sandstone, siltstone, and locally quartzite, with a conglomerate unit at its base. The formation ranges from 7.5 to $30.5 \mathrm{~m}$ in thickness.

- The Walnut Formation consists of interbedded shale, sand, argillaceous limestone, and marl. Large marine fossils are common. The formation has a maximum thickness of $6 \mathrm{~m}$.

- The Comanche Peak Limestone is layered limestone interbedded with thin shale layers. Large marine fossils are common. The formation is as much as about $11 \mathrm{~m}$ thick.
- The Edwards Limestone is massive to thickly bedded limestone, locally dolomitic with chert. The formation ranges from 45 to $52 \mathrm{~m}$ in thickness.

\section{Miocene-Pliocene Ogallala Formation}

The Miocene-Pliocene Ogallala Formation is the primary groundwater aquifer and source of potable water in the Southern High Plains (Nativ, 1988; Mullican and others, 1997). The Ogallala Formation within the Southern High Plains, sometimes called the "Ogallala Group," consists of alluvial sediments that include coarse gravel, silt, and clay; local interbedded eolian deposits; and buried soil horizons (Gustavson, 1996). The Ogallala sediments were deposited by fluvial processes on a widespread, variably incised erosional surface, spreading in all directions as an alluvial apron across this region during the late Tertiary (Miocene and early Pliocene) (Frye and others, 1982; Reeves and Reeves, 1996). The Ogallala Formation in the Southern High Plains is interpreted as the erosional remnant of an extensive sheet of continental sediments derived from bedrock sources in the southern Rocky Mountains, which was deposited on a mature erosional surface of Cretaceous, Triassic, and Permian rocks. In the Southern High Plains, Ogallala deposits can variably rest directly upon strata of the Triassic Dockum Group or can lie in contact with the eroded surface of Lower Cretaceous rocks (Brand, 1956a). On the upper surface of the Ogallala, well-developed zones of thick-layered caliche (as much as several meters thick) can form the caprock escarpments that define the eastern boundary of the Southern High Plains in Texas and the western boundary in southern New Mexico (Frye and others, 1982).

In the Southern High Plains region, the Ogallala Formation (or Group) is locally divided into two units: the lower Pliocene Couch unit and the overlying middle Pliocene Bridwell unit (Evans, 1956; Winkler, 1985) (fig. 4). Vertebrate fossils in each of the formations reveal the age of each unit. The Couch unit is exposed in washes and escarpments just east of the eastern escarpment of the Southern High Plains (east and southeast of Lubbock) and can lie unconformably on either Triassic or Cretaceous strata. It contains a basal interval of fluvial cross-bedded sands and gravels, which is overlain by an upper member of unstratified, calcareous, clayey sands. The Bridwell unit, which forms the upper parts of the Ogallala in this region, rests unconformably on the Couch unit strata; where the Couch unit is absent, the Bridwell strata rest on Triassic and Cretaceous rocks. Most of the Bridwell unit consists of stratified, unconsolidated clay, with local channel deposits in the upper parts of the formation. The Bridwell strata are interpreted as channel and floodplain sediments deposited by broad, aggrading streams (Evans, 1956; Winkler, 1985).

An alluvial paleochannel of the Ogallala Formation locally known as the "Slaton Channel," about $0.8 \mathrm{~km}$ wide and 15.25 to $18.3 \mathrm{~m}$ thick, is exposed east of Slaton. The Slaton Channel has been and is currently mined as a source of aggregate (Winn, 2015). This paleochannel is adjacent to an area in Yellow House Canyon (fig. 2) that was drilled by Kerr-McGee 
Discovery and Character of Pleistocene Calcrete Uranium Deposits in the Southern High Plains of West Texas, U.S.

in the late 1970s; it was selected for drilling based on radiometric anomalies detected in an airborne survey.

The ancestral Pecos River system spread a vast apron of overlapping and coalescing alluvial sediments, which is preserved as the Ogallala Formation (Wood, 2002). However, in the late Pliocene, because of progressive headward erosion moving northward, the ancestral Pecos River likewise moved northward, where it pirated the channels of the Southern High Plains that previously flowed eastward; this led to the establishment of the routes of the modern Pecos and Canadian Rivers (Reeves, 1972; Gustavson and Finley, 1985; Gustavson and Winkler, 1988). This stream piracy cut off stream flows and fluvial input to the Southern High Plains, ending Ogallala Formation deposition in the region and contributing to the aridity of the plains during much of the period that followed.

Subsequently, shallow valleys ("draws") were cut through the caliche cap of the Ogallala during relatively wet glacial periods and then partly filled with fluvial, eolian, and lacustrine deposits during relatively dry interglacial periods (Frye and Leonard, 1968; Holliday, 1995). Within the Ogallala and overlying Blackwater Draw Formations, numerous calcic horizons indicate periods when evapotranspiration exceeded precipitation, resulting in the precipitation and formation of calcium carbonate (caliche layers) under arid to semiarid conditions (Gustavson and Winkler, 1988; Holliday, 1995; Gustavson, 1996; Gustavson and Holliday, 1999).

\section{Lower Pleistocene Blanco Formation}

The type section for the Blanco Formation is at "Mount Blanco," a small white hill located about $60 \mathrm{~km}$ northeast of Lubbock and $14.5 \mathrm{~km}$ north of Crosbyton, Tex. (at lat $33.79139^{\circ} \mathrm{N}$., long $101.25306^{\circ} \mathrm{W}$.). The Blanco Formation, composed of light gray, bentonitic clay, sand, freshwater limestone, and ash layers, was deposited locally in an early Pleistocene basin in lacustrine environments on the upper surface of the Pliocene Ogallala Formation (Evans, 1956; Holliday, 1988). An abundance of diagnostic vertebrate fossils indicates that the Blanco Formation is early Pleistocene in age. Based on an interbed of the Guaje Ash at the type section, Holliday (1988) concluded that deposition of the Blanco sediments ended about 1.6 Ma or earlier. Ash layers, such as those in the Blanco Formation, are rare and not widespread in the Southern High Plains.

\section{Middle Pleistocene Tule Formation}

The strata of the Tule Formation are lacustrine deposits similar to those of the Blanco Formation. The type locality of the Tule Formation is about $110 \mathrm{~km}$ north-northeast of Lubbock, Tex.; similar deposits (that are likely equivalent) also occur in Yellow House Canyon, east of Slaton (Evans, 1956). The Tule Formation consists mainly of bentonitic clay interbedded with medium- to fine-grained sand and a thin zone of freshwater limestone. Margins of the formation locally contain gravel and layers of volcanic ash resting on Pliocene rocks (Ogallala Formation; Evans, 1956; Schultz, 1986). The basin that hosts the Tule deposits is over $11 \mathrm{~km}$ long and elongate in an east-west orientation (Evans, 1956). In the center of the basin, Tule Formation rocks lie unconformably on Triassic red beds (Dockum Group).

\section{Upper Pleistocene Tahoka Formation}

The strata of the Tahoka Formation consist of weakly coherent, friable layers of clay, silt, and fine-grained sand, locally calcareous and gypsiferous, that are interpreted as lacustrine sediments deposited during the Wisconsinan period (Frye and Leonard, 1957; Hall, 2001; Wood, 2002; Rich, 2013). In some areas, fine-grained facies of the formation laterally grade to gravel deposits. The Tahoka Formation is best exposed in the rims of approximately 30 large saline lakes of the Southern High Plains (Goolsby, 1975) (fig. 3).

A geochronology and paleoenvironmental study by Hall (2001) used radiocarbon ages of organic matter as well as pollen analysis of Tahoka Formation strata at Upper White Lake, a saline lake about $115 \mathrm{~km}$ northwest of Lubbock (fig. 3). Hall's study identified several periods of lake filling between 20,000 and $17,000{ }^{14} \mathrm{C}$ years before present, during the last glacial maximum (late Wisconsinan). He suggests possible drying of the lake by $14,000{ }^{14} \mathrm{C}$ years before present (Hall, 2001).

Wood (2002) reported ages of tufa layers in the Tahoka Formation on the banks of Double Lakes, Tex., as late Wisconsinan. The lower strata were revealed to have been deposited approximately 51 kilo-annum (ka) by a 3-m-thick tufa at Double Lake; the middle section was dated at $42 \mathrm{ka}$, and the upper meter was dated at approximately $24 \mathrm{ka}$.

\section{Pleistocene Lacustrine Deposits that Host the Uranium Deposits}

Calcareous sediments that were likely deposited in saline lakes are the host strata for the Sulphur Springs Draw and Buzzard Draw uranium deposits. These lakes probably formed during dry interglacial periods when evaporation exceeded water supply in the region. In the exploration model employed by Kerr-McGee, the lacustrine strata that host the Sulphur Springs Draw and Buzzard Draw uranium deposits were genetically associated with a large Pleistocene lake located downstream to the south. This large saline lake has been named "Lake Lomax." It is the largest Pleistocene lake identified in the Southern High Plains region and is located near the southeastern edge of the province, just west of Big Spring, Tex. (fig. 3). As defined by Frye and Leonard (1968), the lake basin is at least $40 \mathrm{~km}$ in length and elongate, trending westnorthwest to south-southeast (fig. 3). Lacustrine sediments composed of fine- to medium-grained sand and gypsum grains interbedded with silt and minor clay define the extent of Lake Lomax (Frye and Leonard, 1968). Modern saline lakes west of Big Spring, such as Natural Dam Lake (fig. 3), may represent evaporating remnants of Lake Lomax. 
Frye and Leonard (1968) reported that upper parts of Lake Lomax strata contain early Wisconsinan molluscan faunas (late Pleistocene), while lower, non-fossiliferous strata of this lake basin may date to the Illinoian. Frye and Leonard (1968) stated that no evidence exists to indicate that a large lake basin existed in the area during the Pliocene, the time of deposition of the upper strata of the Ogallala Formation. They interpret that Lake Lomax ultimately drained through an outlet that formed west of Big Spring, Tex. A detailed model for the formation, lakelevel fluctuations, and ultimate draining of Lake Lomax is described by Frye and Leonard (1968).

The chronostratigraphic relationship between the uranium-bearing lacustrine strata, the Tahoka Formation, and the former Lake Lomax remains uncertain. At most of its exposures in the region, the Tahoka Formation rests on alluvial sediments of the Miocene-Pliocene Ogallala Formation. In contrast, in the Sulphur Springs Draw and Buzzard Draw deposits, the uranium-bearing lacustrine strata lie directly on red-bed siltstones and sandstones of the Triassic Dockum Group.

As part of this USGS study, we sampled strata immediately adjacent to the Sulphur Springs Draw deposit. One sample revealed a thin ( $2 \mathrm{~cm}$ thick) tephra layer composed of glass shards coated with clay (sample location at lat $32.45244^{\circ} \mathrm{N}$., long $-101.86386^{\circ} \mathrm{W}$.). Age determinations of this ash layer by the USGS Tephrochronology Project determined that this ash was Lava Creek B with an age of $631 \pm 4 \mathrm{ka}\left({ }^{40} \mathrm{Ar}{ }^{39} \mathrm{Ar}\right.$ method, Fish Canyon standard, 28.17 Ma, Matthews and others, 2015); its eruptive source is in the Yellowstone National Park region of Wyoming. The Lava Creek B ash in this region occurs in the upper part of the Tule Formation (middle Pleistocene), thus suggesting that strata of the Tule Formation are the host for the Sulphur Springs Draw uranium deposit.

Kerr-McGee's internal geologic reports suggest that the Pleistocene lacustrine complexes that are underlain by Triassic red beds of the Dockum Formation are the settings found to host the strongest uranium mineralization discovered thus far, as exemplified by both the Sulphur Springs Draw and Buzzard Draw deposits. In some areas of the Southern High Plains, Cretaceous strata directly underlie the Pliocene sedimentary deposits. However, in the region with the two known uranium deposits, Brand (1956b) showed that in most of the area Triassic rocks directly underlie the Pliocene strata (Ogallala Formation) and that Cretaceous strata are absent.

\section{Quaternary Blackwater Draw Formation and Holocene Sediments}

Transitioning from the late Pleistocene to the middle Holocene, the hydrology of the Southern High Plains region shifted from flowing streams to almost entirely standing water because of a significant climate change that decreased precipitation across the region (Holliday, 1995). Less surface and groundwater input led to the development of extensive eolian environments across the region. Wind deflation of the exposed Southern High Plains surface resulted in eolian deposits.

The Quaternary Blackwater Draw Formation covers much of the Southern High Plains of northwestern Texas (fig. 3). The unit consists of eolian sand, silt, and sandy mud interbedded with at least six buried calcareous soil horizons that are each 1-2 m thick (Holliday, 1989; Gustavson, 1996; Gustavson and Holliday, 1999). Studies suggest that accumulation of the soil layers occurred during periods of prolonged aridity; according to Holliday (1989, p. 1598), "each cycle of sedimentation-stability lasted for several hundred thousand years and that [sic] the last depositional event occurred at least several tens of thousands of years ago." The sediments were subsequently modified by pedogenic processes. Deposition of the formation occurred during much of the Quaternary, as evidenced by interbedded layers of the 0.62-m.y. Lava Creek B ash and the 1.61-m.y. Guaje Ash (Holliday, 1989, 1990).

Drainage in the Blackwater Draw Formation, which forms the modern surface of the Southern High Plains, is through numerous small playas. Approximately 20,000 small playa basins have been recognized on the surface of the Southern High Plains (Texas Department of Water Resources, 1980; Gustavson and others, 1995). The playa basins contain ephemeral alkaline lakes that are typically less than $1 \mathrm{~km}$ in diameter and no more than $4 \mathrm{~m}$ in depth (Wood and Osterkamp, 1984). Interbedding of Blackwater Draw Formation strata and playa sediments suggest that these playa basins formed during the Quaternary (Gustavson and others, 1995).

Several studies incorporating stratigraphic, chemical, and isotopic evidence suggest that recharge of the Ogallala aquifer system occurs mostly through these playas (Scanlon and others, 1994; Gustavson and others, 1995; Wood and Sanford, 1995; Mullican and others, 1997). Although the playas only compose approximately 6 percent of the Southern High Plains, much less recharge occurs in the areas between the playas (Scanlon and others, 1994; Gustavson and others, 1995; Wood and Sanford, 1995; Mullican and others, 1997). By collecting runoff and focusing recharge into the Ogallala aquifer, the playas have a significant role in that they are the primary supply of domestic and agricultural waters to the region (Gustavson and others, 1995).

Holocene surficial units across the Southern High Plains include sedimentary deposits from sand sheets, dune sands, alkali flats, caliche, and playas, as well as ponds, alluvium, and small stream terraces along draws. 


\section{Kerr-McGee Corporation's Exploration Program and Discoveries in the Southern High Plains}

\section{Early Exploration for Triassic Red-Bed Uranium Deposits}

Kerr-McGee's exploration in the region began in the 1960 s, with its original focus on the potential for uranium deposits within the Permian-Triassic unconformity in the Midland Basin area, near the eastern escarpment of the Southern High Plains of Texas. In this region, Kerr-McGee adopted a model of potential uranium mineralization in the Triassic Dockum Group strata of the Southern High Plains because of its general lithologic and facies similarities to uranium-bearing red beds and channels of the Triassic Chinle Formation in southeastern Utah and northeastern Arizona (Finch, 1991). Specifically, the uranium potential of the Dockum Group was investigated as an analogue to Lisbon Valley uranium deposits of the Colorado Plateau (Wood, 1968). In the Southern High Plains, Triassic red-bed sedimentary rocks of the Dockum Group (figs. 3 and 4) are considered generally correlative with the Chinle Formation of the Colorado Plateau (McGowen and others, 1979).

In the Midland Basin area of west Texas, Kerr-McGee initially focused on an area in the northeastern part of Garza County, about $65 \mathrm{~km}$ east-southeast of Slaton, Tex. (fig. 2), which contains four previously known uranium prospects within Triassic strata of the Dockum Group. Locations and descriptions of these uranium occurrences are provided in Hayes (1956) and Finch (1975). A Kerr-McGee internal report noted that (1) in adjacent Lynn County, directly west of the uranium prospects (an area about 6-8 $\mathrm{km}$ south of Slaton, Tex.), gamma-ray anomalies were found in several oil well logs where basal Triassic Dockum Group sandstones reach their maximum thickness and (2) water wells drilled in this same area showed that groundwaters in the same stratigraphic horizon contain anomalously high amounts of uranium and radium. As a result, Kerr-McGee drilled seven prospective areas in Lynn and Terry Counties of west Texas. In a memorandum dated April 5, 1979, Kerr-McGee stated, "Drilling [in these prospects] has been discontinued due to very discouraging results. Only 9 of the 122 holes drilled were anomalous, and none of these exceeded twice background in strength. The rest of the holes were barren." Apparently, these seven prospect areas were selected primarily on the basis of groundwater samples with high uranium concentrations, such as 100-350 parts per billion (ppb). The holes were drilled at quarter-mile to half-mile spacing.

\section{Exploration Program Transition to Yeelirrie Uranium Deposits}

In May 1973, Kerr-McGee initiated a new uranium exploration program in the Southern High Plains that shifted its focus towards the potential for surficial uranium deposits similar to the Yeelirrie ore bodies of Western Australia (Carlisle, 1978; Cameron, 1984).

Kerr-McGee's exploration project focused initially on the use of its proprietary ARDA (Airborne Radiometric Detection Apparatus) technique. Its regional airborne radiometric reconnaissance of the Southern High Plains included the extent of Ogallala Formation outcrops from the vicinity of MidlandOdessa in the south to about Amarillo in the north. This airborne reconnaissance survey located several radiometric anomalies near the edge of the Ogallala caprock escarpment along the eastern margin of the Southern High Plains in Texas. These anomalous areas were then inspected on the ground by Kerr-McGee geologists.

A radiometric anomaly reading about 1.5 to 2 times background values was detected by the airborne reconnaissance survey in part of Yellow House Canyon, which is about $10 \mathrm{~km}$ east of Slaton, Tex. (fig. 2). A separate aerial radiometric survey over the region during this same time period, flown as part of the U.S. Department of Energy National Uranium Resource Evaluation (NURE) Program (McGowen and others, 1981; Hill and others, 2009), also detected radiometric anomalies within this same area of Yellow House Canyon. This anomalous area was visited by Kerr-McGee geologists, who traced uranium mineralization to conglomeratic channel sandstone thought to be of Ogallala age. Company memoranda indicate that assays of outcrops of conglomeratic sandstone and greenish siltstone revealed concentrations of 0.034 to 0.053 percent $\mathrm{U}_{3} \mathrm{O}_{8}$. This area was then explored by 27 shallow drill holes, each less than $30 \mathrm{~m}$ in depth. Only six of the holes were barren (background radiation levels were detected), but the highest uranium mineralization encountered was 0.028 percent $\mathrm{U}_{3} \mathrm{O}_{8}$. Based on these results, the short-lived exploration near Slaton was abandoned.

Recent sampling of outcrops in by the USGS in the Yellow House Canyon (this study) near Kerr McGee's anomalous areas found enrichments in uranium and vanadium in strata of the Blanco Formation and the Couch unit (Ogallala Group) (table 2). The highest uranium values were found in a calcareous bed in the upper Blanco Formation (142 ppm uranium) and very fine grained calcareous sandstone in the Couch unit (107 ppm uranium). Samples of a conglomerate bed in the Couch unit also showed anomalous uranium content (67 and $71 \mathrm{ppm}$ uranium). This conglomerate may correspond to the conglomeratic channel sandstone thought to be of Ogallala age, the rock unit identified by Kerr-McGee as the source of airborne radiometric anomalies in this area. In addition to uranium, calcareous clastic sediments of the Couch unit in this area show anomalous concentrations of vanadium (124 to $529 \mathrm{ppm}$ vanadium). The anomalous uranium and vanadium concentrations in calcareous 
Table 2. Concentrations of selected elements in samples collected in 2014 and 2015 from outcrops within the general area in which 1970s reconnaissance airborne radiometric surveys flown by Kerr-McGee and the National Uranium Resource Evaluation program detected radiometric anomalies (1.5 to 2 times background). This area is about 10 kilometers east of Slaton, Crosby County, Texas. Samples are presented in stratigraphic order with samples from the youngest strata at the top.

[Datum for latitude and longitude values is World Geodetic System 1984 (WGS84). Al, aluminum; As, arsenic; Ba, barium; Ca, calcium; Cu, copper; Fe, iron; K, potassium; Li, lithium; Mg, magnesium; Mn, manganese; Mo, molybdenum; P, phosphorus; Pb, lead; Sr, strontium; Th, thorium; U, uranium; V, vanadium; Zn, zinc; Zr, zirconium; wt\%, weight percent; ppm, parts per million]

\begin{tabular}{|c|c|c|c|c|c|c|c|c|c|c|c|c|c|c|c|c|}
\hline \multirow[b]{2}{*}{ Sample } & \multirow[b]{2}{*}{ Latitude } & \multirow[b]{2}{*}{ Longitude } & \multirow[b]{2}{*}{ Formation } & \multicolumn{13}{|c|}{ Concentration ${ }^{1}$} \\
\hline & & & & $\begin{array}{c}\mathbf{A l} \\
\mathbf{w t} \%\end{array}$ & $\begin{array}{c}\mathbf{C a} \\
\mathbf{w t} \%\end{array}$ & $\begin{array}{c}\text { Fe } \\
\text { wt } \%\end{array}$ & $\begin{array}{c}\mathbf{K} \\
\mathbf{w t} \%\end{array}$ & $\begin{array}{c}\mathbf{M g} \\
\mathbf{w t} \%\end{array}$ & $\begin{array}{c}\text { Mn } \\
\text { wt } \%\end{array}$ & $\begin{array}{l}\mathrm{Ba} \\
\mathrm{ppm}\end{array}$ & $\begin{array}{c}\mathrm{Li} \\
\mathrm{ppm}\end{array}$ & $\begin{array}{c}\mathrm{Sr} \\
\mathrm{ppm}\end{array}$ & $\underset{\text { ppm }}{\mathbf{U}}$ & $\begin{array}{c}\mathbf{V} \\
\mathrm{ppm}\end{array}$ & $\begin{array}{c}\mathrm{Zn} \\
\mathrm{ppm}\end{array}$ & $\begin{array}{c}\mathrm{Zr} \\
\mathrm{ppm}\end{array}$ \\
\hline USGS-10 & 33.43332 & -101.53155 & Blanco & 0.53 & 5.65 & 0.18 & 0.36 & 3.57 & 0.004 & 699 & 20 & $>10,000$ & 142 & 31 & 12 & 204 \\
\hline USGS-9 & 33.43340 & -101.53175 & Blanco & 1.12 & 2.95 & 0.41 & 0.69 & 2.15 & 0.007 & 381 & 20 & 813 & 3 & 33 & 10 & 223 \\
\hline 05-TX15 & 33.43319 & -101.53231 & Blanco & 2.21 & 3.9 & 1.26 & 1.1 & 2.96 & 0.013 & 240 & 37 & 1,238 & 14 & 327 & 17 & 162 \\
\hline USGS-8 & 33.43350 & -101.53227 & Blanco & 1.46 & 11.1 & 0.54 & 0.74 & 7.11 & 0.024 & 348 & 30 & 1,140 & 33 & 136 & 18 & 107 \\
\hline 04-TX15 & 33.43339 & -101.53239 & Blanco & 1.56 & 7.5 & 0.48 & 0.7 & 4.57 & 0.013 & 522 & 23 & 741 & 42 & 139 & 9 & 152 \\
\hline USGS-7 & 33.43487 & -101.52974 & Ogallala & 0.99 & 15.9 & 0.37 & 0.41 & 8.18 & 0.007 & 245 & 20 & 8,700 & 18 & 36 & 14 & 90 \\
\hline USGS-6 & 33.43643 & -101.53255 & Ogallala & 0.76 & 12.2 & 0.3 & 0.39 & 6.63 & 0.018 & 361 & 20 & 1,860 & 71 & 99 & 8 & 84 \\
\hline USGS-5 & 33.43765 & -101.53110 & Ogallala & 0.66 & 27.9 & 0.25 & 0.3 & 1.34 & 0.004 & 342 & $<10$ & 2,350 & 3 & 13 & 9 & 67 \\
\hline 01-TX15 & 33.44503 & -101.53622 & Couch & 1.90 & 5.0 & 0.75 & 0.9 & 0.47 & 0.011 & 445 & 11 & 135 & 2 & 41 & 9 & 255 \\
\hline USGS-1 & 33.44353 & -101.53593 & Couch & 2.96 & 5.06 & 1.26 & 1.32 & 3.76 & 0.029 & 530 & 30 & 510 & 45 & 522 & 24 & 230 \\
\hline 03B-TX15 & 33.44344 & -101.53628 & Couch & 2.76 & 5.2 & 1.32 & 1.2 & 3.84 & 0.032 & 279 & 29 & 575 & 40 & 529 & 19 & 177 \\
\hline USGS-3 & 33.44353 & -101.53593 & Couch & 0.78 & 10.7 & 0.29 & 0.36 & 5.94 & 0.014 & 146 & 10 & 622 & 107 & 124 & $<5$ & 94 \\
\hline USGS-4 & 33.44146 & -101.53536 & Couch & 0.87 & 11.7 & 0.34 & 0.45 & 6.51 & 0.009 & 249 & 20 & 947 & 72 & 186 & 14 & 46 \\
\hline USGS-2 & 33.44353 & -101.53593 & Couch & 1.34 & 6.99 & 0.45 & 0.79 & 3.92 & 0.053 & 2,250 & 10 & 737 & 67 & 403 & 10 & 56 \\
\hline 03A-TX15 & 33.44344 & -101.53628 & Couch & 1.37 & 7.3 & 0.49 & 0.7 & 3.99 & 0.054 & 2,244 & 13 & 692 & 71 & 366 & 6 & 78 \\
\hline 02A-TX15 & 33.45217 & -101.52469 & Dockum & 2.62 & 7.3 & 0.76 & 0.9 & 0.37 & 0.101 & 223 & 13 & 305 & 2 & 40 & 13 & 139 \\
\hline 02B-TX15 & 33.45217 & -101.52469 & Dockum & 5.94 & 8.4 & 2.68 & 2 & 1.44 & 0.122 & 213 & 34 & 637 & 5 & 192 & 49 & 183 \\
\hline \multicolumn{17}{|c|}{ Sample descriptions } \\
\hline
\end{tabular}

USGS-10 Calcareous nodules eroding out of friable calcareous bed; upper Blanco Formation.

USGS-9 Slightly calcareous, very fine grained sandstone; apparently Blanco Formation.

05-TX15 Calcareous fine grained sandstone; apparently Blanco Formation.

USGS-8 Caliche nodules in calcareous, fine-grained sandstone; apparently Blanco Formation.

04-TX15 Calcareous, fine-grained sandstone; apparently Blanco Formation.

USGS-7 Bedded caliche; forms caprock at upper surface of Ogallala Group in this area.

USGS-6 Massive, very fine grained caliche; in cap rock unit in uppermost Ogallala Group.

USGS-5 Weathered caliche with calcareous pebbles; in upper part of Ogallala Group.

01-TX15 Fine-grained sandstone; Couch Formation.

USGS-1 Calcareous, silty to very fine grained sandstone; Couch Formation.

03B-TX15 Fine-grained sandstone; Couch Formation.

USGS-3 Calcareous, very fine grained sandstone; Couch Formation.

USGS-4 Calcareous, very fine grained sandstone; Couch Formation.

USGS-2 Calcareous, clayey conglomerate with quartzite and chert pebbles in coarse- to fine-grained sand matrix; Couch Formation.

03A-TX15 Calcareous conglomerate; Couch Formation.

02A-TX15 Red mudstone and siltstone (red bed); upper Dockum Group.

02B-TX15 Greenish-gray mudstone and siltstone; upper Dockum Group. Contains 29 ppm Cu, 10 ppm Th.

${ }^{1}$ Maximum concentrations of some other elements in Blanco, Ogallala, and Couch Formation samples above: $\mathrm{P}$, maximum of 0.06; As, all <30 ppm (limit of detection); Cu, 9 ppm; Mo, 6 ppm; $\mathrm{Pb}, 20$ ppm; Th, 5 ppm. 
sediments suggest that a calcrete uranium deposit may have occurred in this area of Yellow House Canyon.

Thick calcareous zones that form cap rock in this area revealed low and moderate values of uranium (samples USGS-7, USGS-6, and USGS-5 with values of 18, 71, and 3 ppm uranium, respectively). The calcareous horizons that form the cap rock are very likely caliche formed by pedogenic processes; however, the layer represented by sample USGS-6 does contain elevated uranium content (71 ppm uranium).

\section{The Discovery of Uranium Deposits}

Two radiometric anomalies identified by Kerr-McGee's regional airborne survey pointed them to areas of uranium mineralization exposed at the surface along Sulphur Springs Draw and Buzzard Draw. Extensive drilling of the two sites resulted in the discovery of shallow uranium deposits, which Kerr-McGee named the Sulphur Springs Draw and Buzzard Draw deposits (figs. 2 and 3; table 1).

\section{Sulphur Springs Draw Deposit}

The most significant cluster of radiometric anomalies identified by Kerr-McGee's regional ARDA survey pointed their researchers to the east side of Sulphur Springs Draw (figs. 2 and 3). Kerr-McGee geologists visited this area and found exposed in a trench "an area of obvious yellow carnotite mineralization in Ogallala caliche with outcrop samples assaying up to $.05 \% \mathrm{U}_{3} \mathrm{O}_{8}$ " (quoted from a Kerr-McGee internal report). The center of this trench exposure is located at lat $32.44203^{\circ} \mathrm{N}$., long $-101.87003^{\circ} \mathrm{W}$. The entire deposit lies within privately owned lands. A NURE flight line flown during the mid-1970s also detected a radiometric anomaly in the vicinity (Geodata International Inc., 1980; Hill and others, 2009). Existence of this exposure of uranium minerals (fig. 5) was briefly noted by Otton (1984) and Finch and others (1995), but neither mentioned Kerr-McGee's drilling program.

The mineralization exposed in this trench occurs as blotches of yellow and greenish-yellow uranium minerals, which coat grains, vugs, and surfaces of small fractures in a calcareous, very fine grained to fine-grained sandstone. Individual blotches of this mineralization are typically no more than $5 \mathrm{~cm}$ in diameter (fig. 5).

Company files indicate that Kerr-McGee drilled at least 669 holes into the Sulphur Springs Draw deposit (fig. 6). The holes were typically no more than $30 \mathrm{~m}$ in depth; each hole was logged by a gamma-radiation probe, and lithologies were recorded based on observations from drill core and cuttings (fig. 7). The subsurface extent of the buried uranium deposits is shown in figure 8. Its uranium resource estimate for this deposit totaled 2,311,259 short tons $(2,096,774 \mathrm{t})$ of ore averaging 0.037 weight percent $\mathrm{U}_{3} \mathrm{O}_{8}(0.031$ weight percent uranium) (table 1).

Kerr-McGee contracted a mineralogic analysis of one drill core from the deposit. This analysis found that the highest-grade intervals (0.021-0.274 weight percent $\left.\mathrm{U}_{3} \mathrm{O}_{8}\right)$ are associated with dolomite, illite, and montmorillonite. All samples of drill core that it analyzed, including ore and subore rock, contained illite and montmorillonite. Calcite was identified in low-grade samples.

As described in company memoranda, the principal uranium mineral identified by Kerr-McGee's study of the drill core is carnotite, which occurs as grain coatings, vug fillings, and fracture coatings in the lacustrine rocks. One company memorandum suggests that tyuyamunite $\left(\mathrm{Ca}\left(\mathrm{UO}_{2}\right)_{2}\left(\mathrm{VO}_{4}\right)_{2} \cdot 5-8 \mathrm{H}_{2} \mathrm{O}\right)$ was also identified. In the Sulphur Springs Draw deposit, uranium mineralization occurs mainly in calcareous sandy siltstone and calcareous mudstone, but it does not appear to be confined to a specific horizon.

Uranium mineralization occurs just above the water table in calcareous siltstones and very fine grained sandstones. The highest radioactivity was found in calcareous mudstones and sandstones. The sediments hosting the deposit have a total thickness of as much as $30 \mathrm{~m}$ and rest directly on Triassic red-bed claystone and siltstone (fig. 7). The drill holes that transected the deposit bottomed in the upper 1 to $2 \mathrm{~m}$ of the Triassic strata.

\section{U.S. Geological Survey Sampling Results from the Sulphur Springs Draw Deposit}

A caliche zone as much as $6 \mathrm{~m}$ thick lies above the uranium-bearing lacustrine sediments and is the caprock unit of the draw. This calcareous cap rock is interpreted to be a pedogenic caliche based on the similarity of its characteristics to those of the caliche layers of the Blackwater Draw Formation in the area (fig. 4). For example, sampling by the USGS found that the caliche cap rock contained only $9 \mathrm{ppm}$ uranium (sample 01G-SSD15, table 3).

Composite grab samples of rocks stained with yellow to greenish-yellow uranium mineralization were collected from exposed rocks in the trench on the western edge of the Sulphur Springs Draw deposit (fig. 5). These samples had uranium concentrations ranging from 100 to $245 \mathrm{ppm}$ and vanadium concentrations ranging from 73 to $107 \mathrm{ppm}$ (table 3 ). The host rocks, dominantly dolomitic, exhibit high magnesium and strontium contents (10-11 and 0.64-6.06 weight percent, respectively).

A scanning electron microscope (SEM) equipped with an energy-dispersive X-ray spectroscopy system (EDS) was used to examine uranium mineralization in two samples from Sulfur Springs Draw (samples 01A-SSD15 and 01B-SSD15, table 3). Secondary and backscattered electron images of the samples were acquired with a FEI Quanta 450 Field Emission Gun Scanning Electron Microscope operating at 15 kilovolts, approximately 2-nanoampere beam current. Energy-dispersive spectra were collected for 30 seconds live-count time with an EDAX Apollo X silicon drift detector. Semiquantitative EDS analyses of the uraniumbearing phases (fig. 9) identified ubiquitous blade-like crystals composed of strontium ( $\mathrm{Sr}$ ), uranium, and vanadium (approximately $\left.(\mathrm{Sr}, \mathrm{Ca})\left(\mathrm{UO}_{2}\right)_{2}\left(\mathrm{VO}_{4}\right)_{2} \cdot 5-8 \mathrm{H}_{2} \mathrm{O}\right)$ intermixed with rhomboid grains with compositions suggesting carnotite 

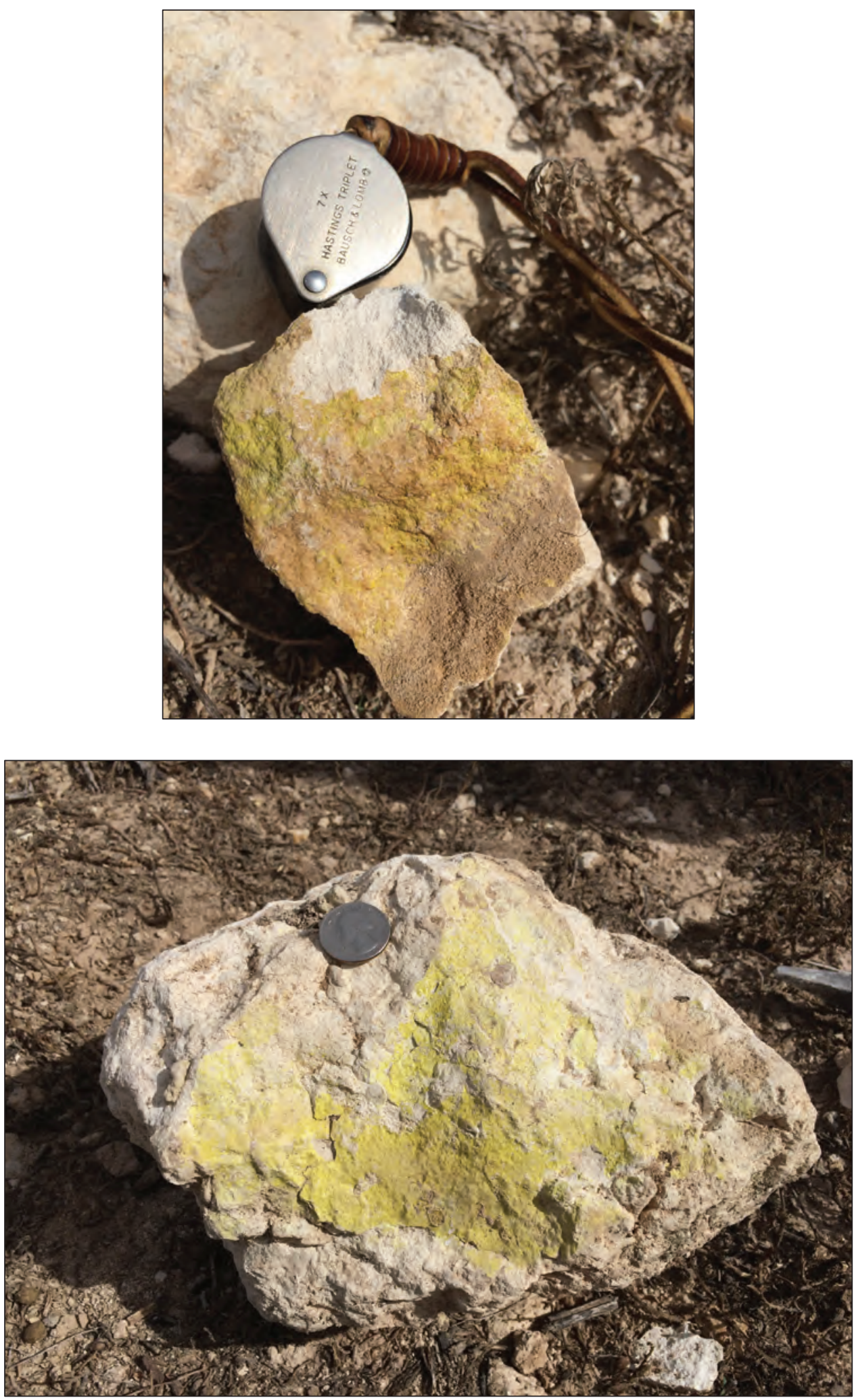

Figure 5. Examples of the yellow and greenish-yellow uranium mineralization exposed in a trench near the western edge of the Sulphur Springs Draw deposit. Mineralization occurs as thin coatings on calcareous, silty sandstone. 


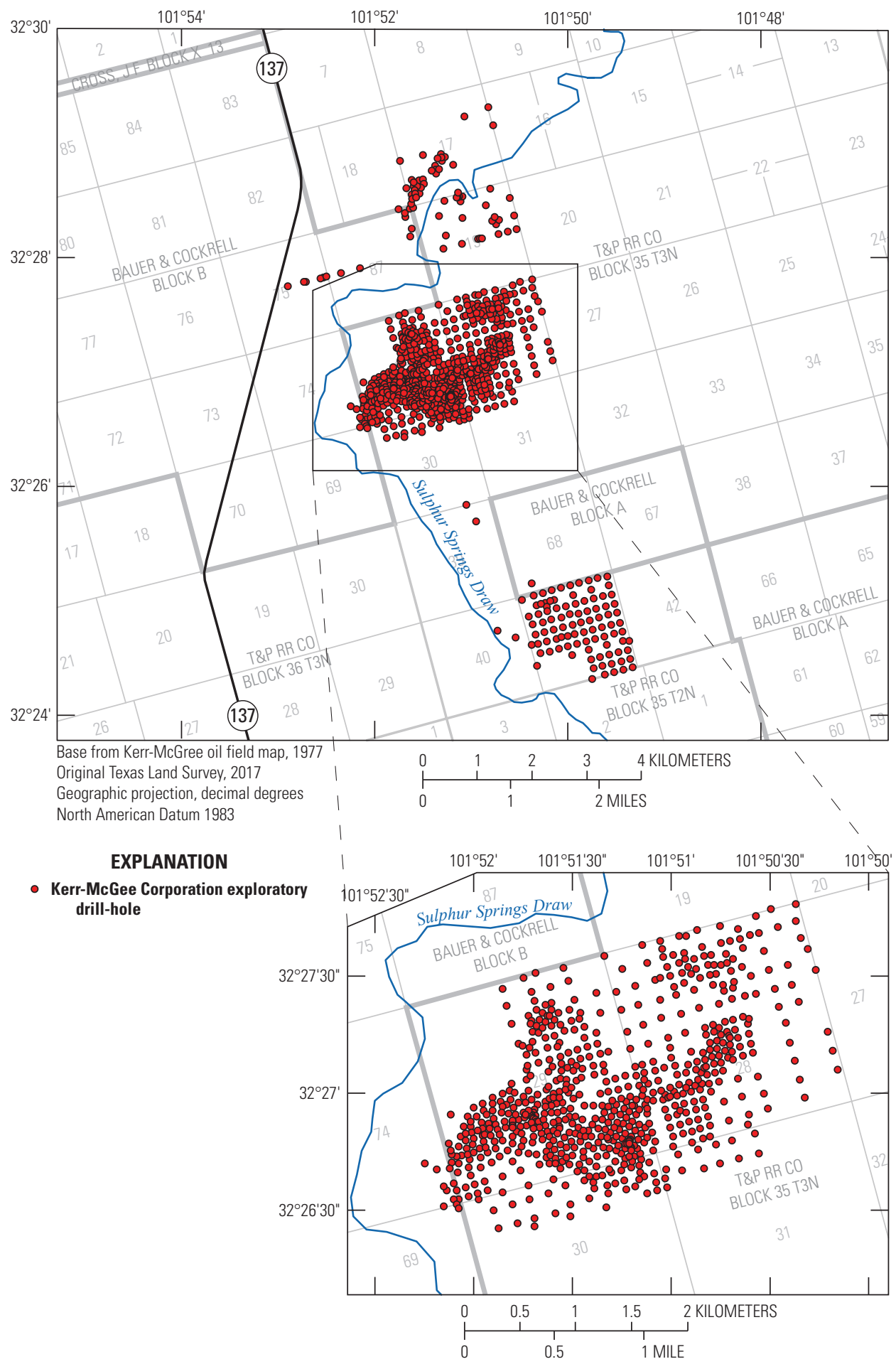

Figure 6. Drill-hole locations (red dots) of Kerr-McGee Corporation's exploratory drilling of the Sulphur Springs Draw deposit. Adapted from Kerr-McGee map dated January 1977. 


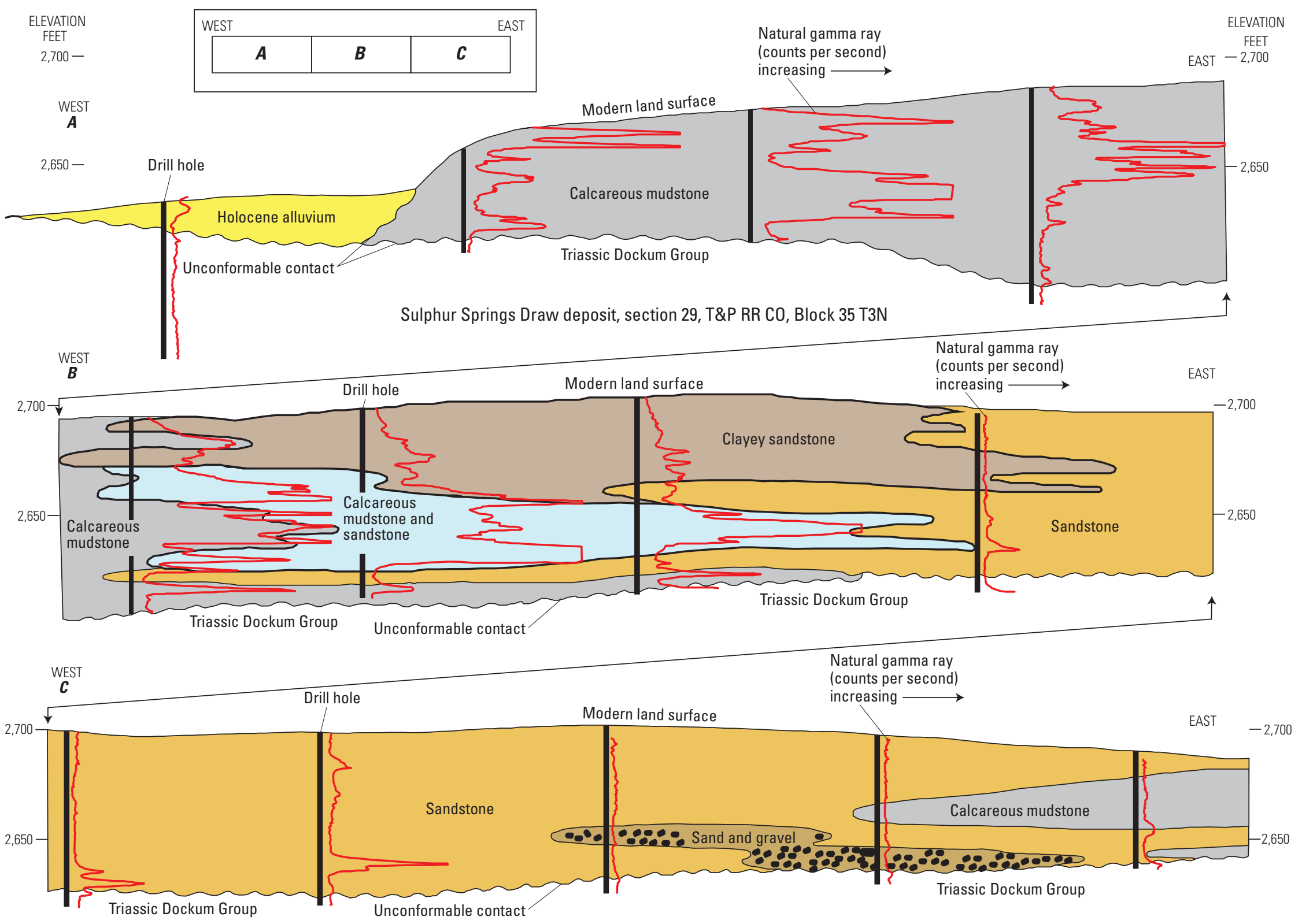

Figure 7. Cross section of the Sulphur Springs Draw deposit based on drilling results, showing lithologies and down-hole gamma-ray measurements (relative scale). Adapted from a hand-drawn cross section in the Kerr-McGee files. 


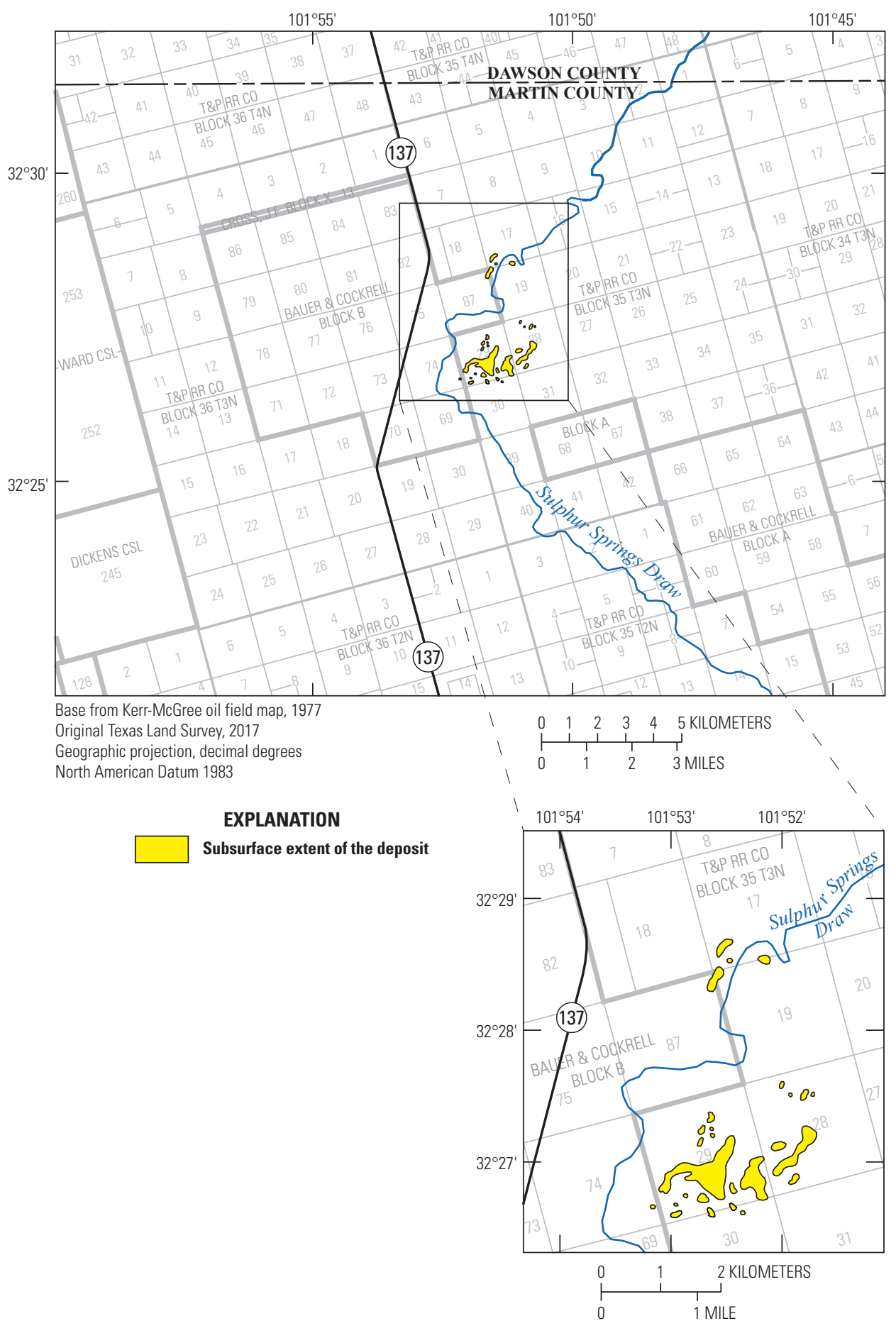

Figure 8. Index map of the Sulphur Springs Draw deposit showing the subsurface extent of the deposit (in yellow) based on drilling by Kerr-McGee Corporation and their interpretive map based on the drilling results. 
Table 3. Concentrations of selected elements in samples collected in 2015 by this study from outcrops near the western edge of the Sulphur Springs Draw deposit, Martin County, Texas. Samples are presented in stratigraphic order with samples from the youngest strata at the top.

[Datum for latitude and longitude values is World Geodetic System 1984. Al, aluminum; As, arsenic; Ba, barium; Ca, calcium; Cu, copper; Fe, iron; K, potassium; Li, lithium; Mg, magnesium; Mn, manganese; Mo, molybdenum; $\mathrm{P}$, phosphorus; $\mathrm{Pb}$, lead; $\mathrm{Sr}$, strontium; Th, thorium; $\mathrm{U}$, uranium; V, vanadium; $\mathrm{Zn}$, zinc; $\mathrm{Zr}$, zirconium; wt\%, weight percent; ppm, parts per million]

\begin{tabular}{|c|c|c|c|c|c|c|c|c|c|c|c|c|c|c|c|c|c|}
\hline \multirow[b]{2}{*}{ Sample } & \multirow[b]{2}{*}{ Latitude } & \multirow[b]{2}{*}{ Longitude } & \multicolumn{15}{|c|}{ Concentration $^{1}$} \\
\hline & & & $\begin{array}{c}\mathbf{A l} \\
\mathbf{w t} \%\end{array}$ & $\begin{array}{c}\mathbf{C a} \\
\mathbf{w t} \%\end{array}$ & $\begin{array}{c}\mathrm{Fe} \\
\mathbf{w t} \%\end{array}$ & $\begin{array}{c}\mathbf{K} \\
\mathbf{w t} \%\end{array}$ & $\begin{array}{l}\mathbf{M g} \\
\mathbf{w t} \%\end{array}$ & $\begin{array}{c}\mathbf{M n} \\
\mathbf{w t} \%\end{array}$ & $\begin{array}{c}\text { As } \\
\text { ppm }\end{array}$ & $\begin{array}{c}\mathrm{Ba} \\
\mathrm{ppm}\end{array}$ & $\begin{array}{c}\mathrm{Cu} \\
\mathrm{Ppm}\end{array}$ & $\underset{\mathrm{ppm}}{\mathrm{Li}}$ & $\begin{array}{c}\mathrm{Sr} \\
\mathrm{ppm}\end{array}$ & $\underset{\mathrm{ppm}}{\mathbf{U}}$ & $\begin{array}{c}\mathbf{V} \\
\mathrm{ppm}\end{array}$ & $\begin{array}{c}\mathrm{Zn} \\
\mathrm{ppm}\end{array}$ & $\underset{\mathrm{ppm}}{\mathrm{Zr}}$ \\
\hline 01G-SSD15 & 32.44203 & -101.87003 & 0.83 & 20.8 & 0.37 & 0.4 & 3.95 & 0.004 & $<30$ & 298 & $<5$ & 28 & 3,796 & 9 & 22 & $<5$ & 53.9 \\
\hline 01A-SSD15 & 32.44203 & -101.87003 & 0.55 & 17.2 & 0.28 & 0.3 & 9.99 & 0.017 & 41 & 539 & $<5$ & 49 & 60,588 & 183 & 87 & $<5$ & 23.6 \\
\hline 01B-SSD15 & 32.44203 & -101.87003 & 0.53 & 19.8 & 0.27 & 0.3 & 11.2 & 0.019 & 47 & 83 & $<5$ & 47 & 6,376 & 136 & 73 & $<5$ & 30.6 \\
\hline 01C-SSD15 & 32.44203 & -101.87003 & 0.49 & 19.5 & 0.26 & 0.2 & 11.2 & 0.02 & 46 & 246 & $<5$ & 36 & 15,095 & 245 & 92 & $<5$ & 21.8 \\
\hline 01D-SSD15 & 32.44203 & -101.87003 & 0.59 & 19 & 0.32 & 0.3 & 11.4 & 0.021 & 36 & 102 & $<5$ & 57 & 9,996 & 217 & 107 & 11 & 18.1 \\
\hline 01E-SSD15 & 32.44203 & -101.87003 & 0.67 & 18.1 & 0.33 & 0.3 & 10.9 & 0.019 & 42 & 199 & $<5$ & 45 & 8,710 & 100 & 74 & 5 & 34.2 \\
\hline 01F-SSD15 & 32.44203 & -101.87003 & 0.73 & 18.6 & 0.37 & 0.3 & 11 & 0.018 & 41 & 109 & 23 & 52 & 6,516 & 166 & 86 & 9 & 24.6 \\
\hline 06-SSD15 & 32.44569 & -101.86836 & 1.89 & 23.9 & 0.87 & 0.8 & 0.95 & 0.013 & 34 & 234 & 7 & 35 & 11,439 & 147 & 176 & 16 & 101 \\
\hline
\end{tabular}

01G-SSD15 Ledge-forming caliche capping the lacustrine strata that host the uranium deposit.

01A-SSD15 Calcareous siltstone and very fine grained sandstone with visible greenish-yellow uranium minerals.

01B-SSD15 Calcareous siltstone and very fine grained sandstone with visible greenish-yellow uranium minerals.

01C-SSD15 Calcareous siltstone and very fine grained sandstone with visible greenish-yellow uranium minerals.

01D-SSD15 Calcareous siltstone and very fine grained sandstone with visible greenish-yellow uranium minerals.

01E-SSD15 Calcareous siltstone and very fine grained sandstone with visible greenish-yellow uranium minerals.

01F-SSD15 Calcareous siltstone and very fine grained sandstone with visible greenish-yellow uranium minerals.

06-SSD15 Calcareous, sandy mudstone exhibiting anomalously high radioactivity.

${ }^{1}$ Maximum concentrations of some other elements in the samples above: $\mathrm{P}$, maximum of $0.03 \%$; Mo, all $<2 \mathrm{ppm} ; \mathrm{Pb}, 10 \mathrm{ppm} ; \mathrm{Th}, 3.7 \mathrm{ppm}$. 
(approximately $\left.\mathrm{K}_{2}\left(\mathrm{UO}_{2}\right)_{2}\left(\mathrm{VO}_{4}\right)_{2} \cdot 3 \mathrm{H}_{2} \mathrm{O}\right)$. Additional, more detailed analyses of these uranium minerals are underway. The uranium minerals occur with micritic dolomite, a latestage strontium-calcium carbonate (fig. 9), celestine $\left(\mathrm{SrSO}_{4}\right)$, and grains of quartz, feldspars, and clay.

$\mathrm{X}$-ray diffraction analyses of the yellow and greenishyellow minerals also identified carnotite and an unspecific strontium-uranium-vanadium mineral (approximately $\left.\left(\mathrm{H}_{2} \mathrm{O}\right)_{2}\left(\mathrm{UO}_{2}\right)_{2} \mathrm{~V}_{2} \mathrm{O}_{8}\right)$, accompanied by dolomite, quartz, calcite, and celestine.

Carnotite is disseminated within the dolomicrite host, where it forms cements and fine veins. Later-stage crusts of carnotite, a strontium-uranium-vanadium mineral, celestine, and strontium-carbonate mineral were deposited in more porous areas of the dolomicrite host. The dolomite-rich matrix indicates that the host rocks could be deemed "dolocrete" rather than calcrete.

Preliminary uranium-series analyses of the unmineralized carbonate host, as well as carbonate associated with carnotiterich crusts, were done as part of this study. The results lead to the interpretation that the carbonate host is the result of mixing in a two-component system, in which the lacustrine carbonate host was deposited prior to about $190 \mathrm{ka}$, and that solutions that resulted in precipitation of carnotite-rich crusts were introduced much later, during the Holocene (Hall and others, 2016). Initial ${ }^{234} \mathrm{U} /{ }^{238} \mathrm{U}$ activity ratios, which are inherited from solution at the time of mineral formation, are distinct for each end member and require the presence of two separate fluid sources. The possible implications of these findings are discussed in the Discussion section.

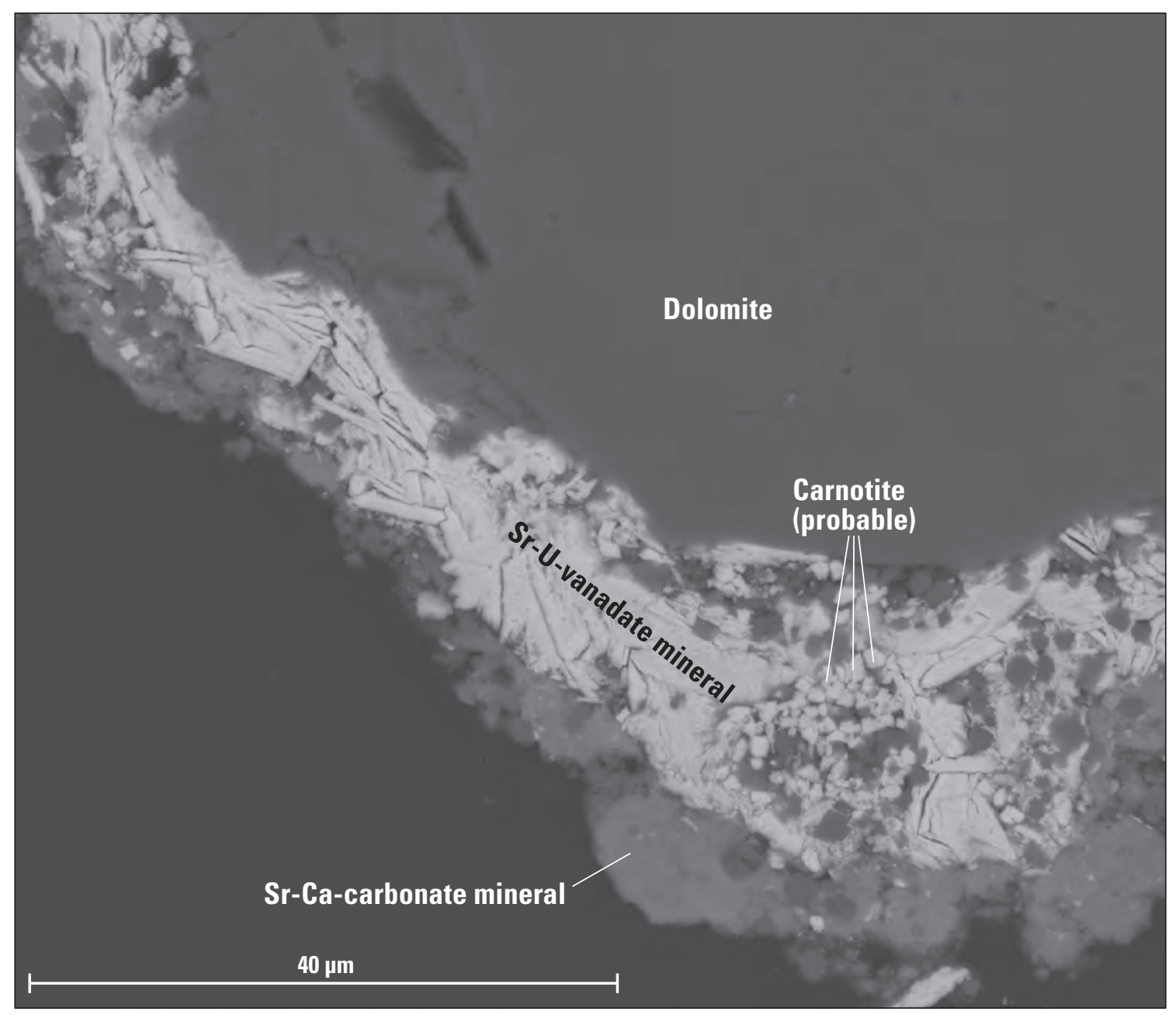

Figure 9. Scanning electron microscope image of uranium mineralization in the Sulphur Springs Draw deposit. Based on elemental compositions measured by an energy-dispersive $\mathrm{X}$-ray spectroscopy system, the rhomboid crystals are likely carnotite, the blade-like crystals are a strontium-uranium-vanadium mineral, and the outer rim of alteration is a strontium-calcium carbonate. (Sr-U, strontium-uranium; $\mathrm{Sr}-\mathrm{Ca}$, strontium-calcium; $\mu \mathrm{m}$, micrometer) 


\section{Buzzard Draw Deposit}

The area that contains the Buzzard Draw deposit originally drew Kerr-McGee's interest because of a radiometric anomaly detected by an airborne survey, an oil-well gammaray log showing increased gamma counts in shallower horizons, and according to one memorandum, "a surface morphology suggestive of lacustrine deposits." Samples of well waters collected as a traverse across the area of the deposit exhibited uranium concentrations, for example, 35 , $41,150,350$, and $520 \mathrm{ppb}$. A sample of well water collected about 0.5 mile $(0.8 \mathrm{~km})$ from the subsequent drilling area contained $770 \mathrm{ppb}$ uranium. Soils at the deposit site showed gamma counts of two to three times background values. A Kerr-McGee memorandum suggested that a surface show of uranium mineralization occurs at Buzzard Creek in Buzzard Draw, apparently along the eastern edge of the deposit. It reported that assays of this surface exposure revealed 0.003 to 0.013 percent $\mathrm{U}_{3} \mathrm{O}_{8}$. No exposures of this mineralization were found at the site of the Buzzard Draw deposit during USGS field research for this study. The land surface is today covered by cotton crops and by oil-well pads.

According to Kerr-McGee files, it drilled at least 305 holes into the Buzzard Draw deposit (figs. 10 and 11). As with the Sulphur Springs Draw deposit, the holes were typically no more than $30 \mathrm{~m}$ in depth; each hole was logged by a gamma-radiation probe, and lithologies were recorded based on observations from drill core and cuttings. A company memorandum noted that the Buzzard Draw deposit most likely extends farther to the north, but the landowner did not allow Kerr-McGee to explore that area. In total, Kerr-McGee estimated that the Buzzard Draw deposit contains $1,023,341$ short tons $(928,375 \mathrm{t})$ of ore with an average content of 0.047 weight percent $\mathrm{U}_{3} \mathrm{O}_{8}(0.04$ weight percent uranium) (table 1).

Uranium mineralization in the Buzzard Draw deposit mainly occurs in a fine- to medium-grained silty, clayey sandstone unit that contains scattered quartz pebbles. Based on company reports, the uranium-rich zone consistently occurs at or near the contact with underlying Triassic red beds of the Dockum Group.

\section{Ore Calculations}

Kerr-McGee's uranium resource calculations for the two deposits (table 1) included resources in the measured, indicated, and inferred categories. Resources classified as potential were not included. The two deposits were drilled on a spacing of $150 \mathrm{ft}(46 \mathrm{~m})$ or less. Thus, the resource figures presented by Kerr-McGee have a relatively high level of confidence.

Kerr-McGee's resources were calculated for deposits measuring at least $3 \mathrm{ft}(0.9 \mathrm{~m})$ thick and containing 0.030 weight percent $\mathrm{U}_{3} \mathrm{O}_{8}$. Individual intercepts frequently exceeded 0.10 percent $\mathrm{U}_{3} \mathrm{O}_{8}$, and the bulk of the resource is present in intervals averaging less than 0.060 percent $\mathrm{U}_{3} \mathrm{O}_{8}$. All resource calculations applied a density of 15 cubic feet per short ton, which was determined by bulk sampling.
Kerr-McGee calculated that the combined resources of the Sulphur Springs Draw and Buzzard Draw deposits total about 3,025,150 metric tons of ore at an average grade of about 0.04 weight percent $\mathrm{U}_{3} \mathrm{O}_{8}$ (table 1). For comparison, Cameco Corporation has reported for its Yeelirrie property in West Australia a total measured and indicated resources of 39,351,000 metric tons of ore at an average grade of 0.12 to 0.16 percent $\mathrm{U}_{3} \mathrm{O}_{8}$ (as of December 31, 2016; Cameco Corporation, 2016).

\section{Additional Exploration in the Area}

During the 1970s, Kerr-McGee drilled hundreds of exploratory holes in the area near the Sulphur Springs Draw and Buzzard Draw deposits (fig. 12). However, aside from uranium mineralization near the Sulphur Springs Draw and Buzzard Draw deposits (figs. 8 and 11), Kerr-McGee did not find other uranium deposits in the area. Company memoranda suggest that Kerr-McGee's exploration program in this region ended around 1981.

\section{Kerr-McGee Corporation's Cost-of-Production Analysis}

In 1981, Kerr-McGee conducted an economic analysis to estimate the total costs to mine and produce yellowcake (milled uranium oxide) from the uranium resources at the Sulphur Springs Draw and Buzzard Draw deposits. At that time, the company leased properties at the two deposits on privately owned fee lands. The shallow depth of these deposits made them potentially attractive for small-scale open-pit mining. The researchers concluded that the remoteness of the properties in relation to existing uranium ore-processing facilities meant the ore would need to be upgraded (through removal of sands and silt) to make shipping for milling cost effective. Its analysis included cost estimates for stripping and mining, onsite upgrading of the ore (by hydro-centrifuge), hauling, milling (to 95 percent recovery), development (infill drilling, permitting, and other factors), and equipment (hydrocentrifuge equipment, onsite offices, facilities, vehicles, and miscellaneous), plus general and administrative expenses. Its estimated total cost of production for the two deposits, including all steps from mining to yellowcake production, was $\$ 29.07$ per pound of $\mathrm{U}_{3} \mathrm{O}_{8}$ (calculated February 1981, as reported in an internal company memorandum).

This cost estimate appears to have ended Kerr-McGee's interest in the Sulphur Springs Draw and Buzzard Draw deposits, as well as the corporation's interest in exploring further for similar deposits in the Southern High Plains region. In its analyses, the researchers suggested that production from the mines would begin in 1985. From a spot market price of $\$ 40$ per pound of $\mathrm{U}_{3} \mathrm{O}_{8}$ in 1980 , the price fell to below $\$ 20$ per pound of $\mathrm{U}_{3} \mathrm{O}_{8}$ in 1981 and continued to stay below this value throughout the 1980s. Thus, it appears that the mining of these deposits during the 1980s would have been an uneconomic proposition for the company. 


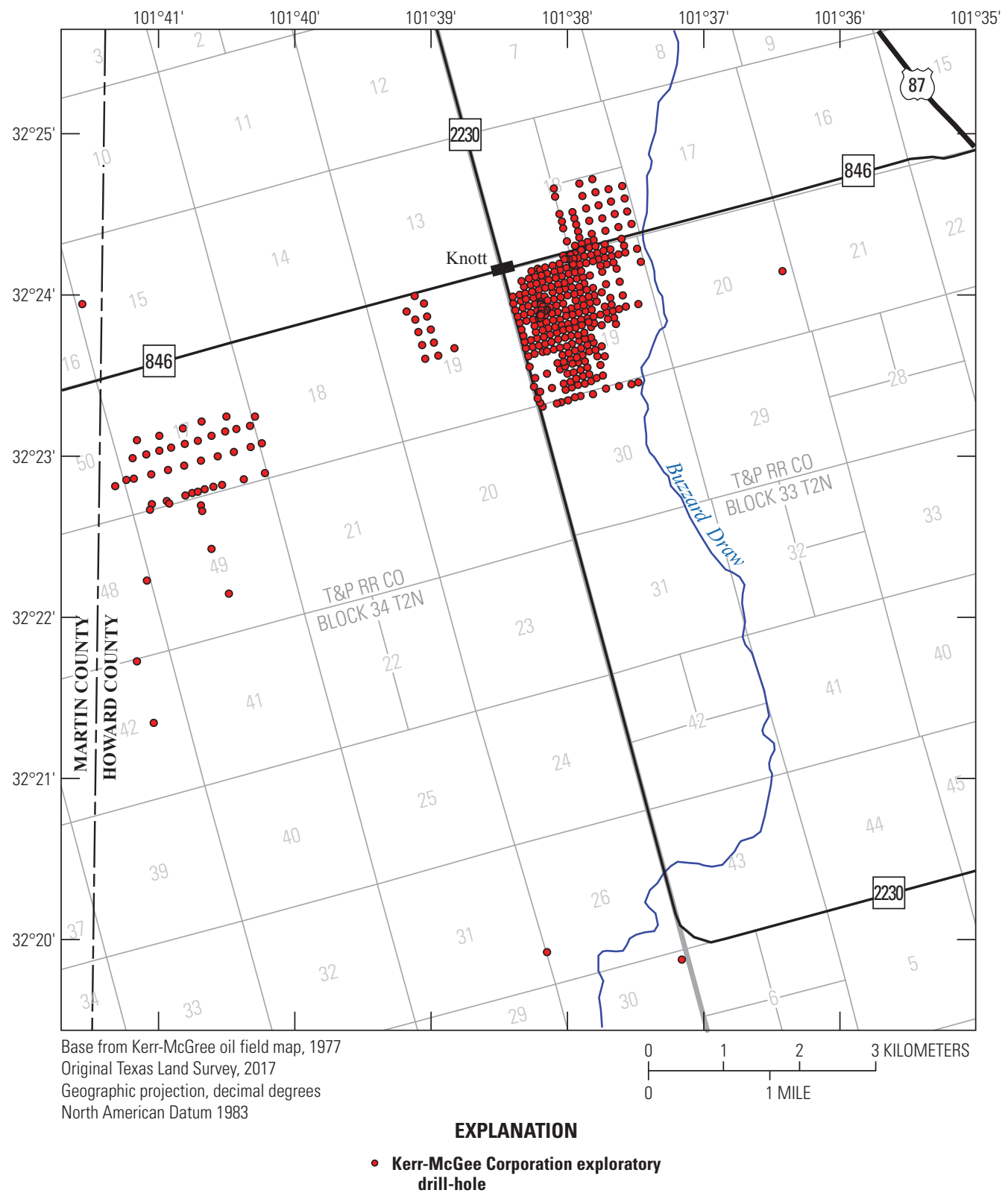

Figure 10. Drill-hole locations (red dots) of Kerr-McGee Corporation's exploratory drilling of the Buzzard Draw deposit. Adapted from Kerr-McGee map dated November 1978. 


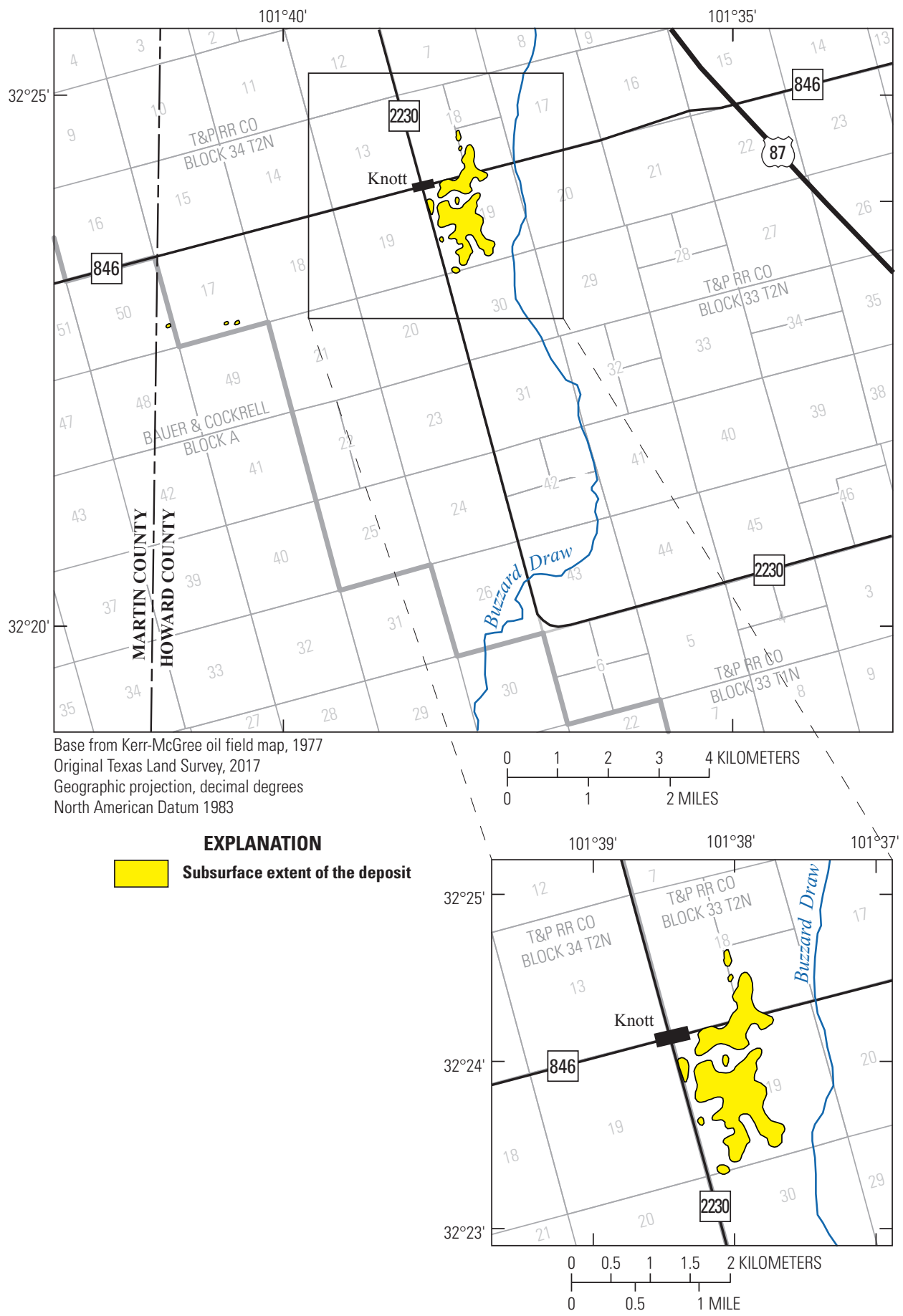

Figure 11. Index map of the Buzzard Draw deposit showing the subsurface extent of the deposit (in yellow) based on drilling by Kerr-McGee Corporation. 


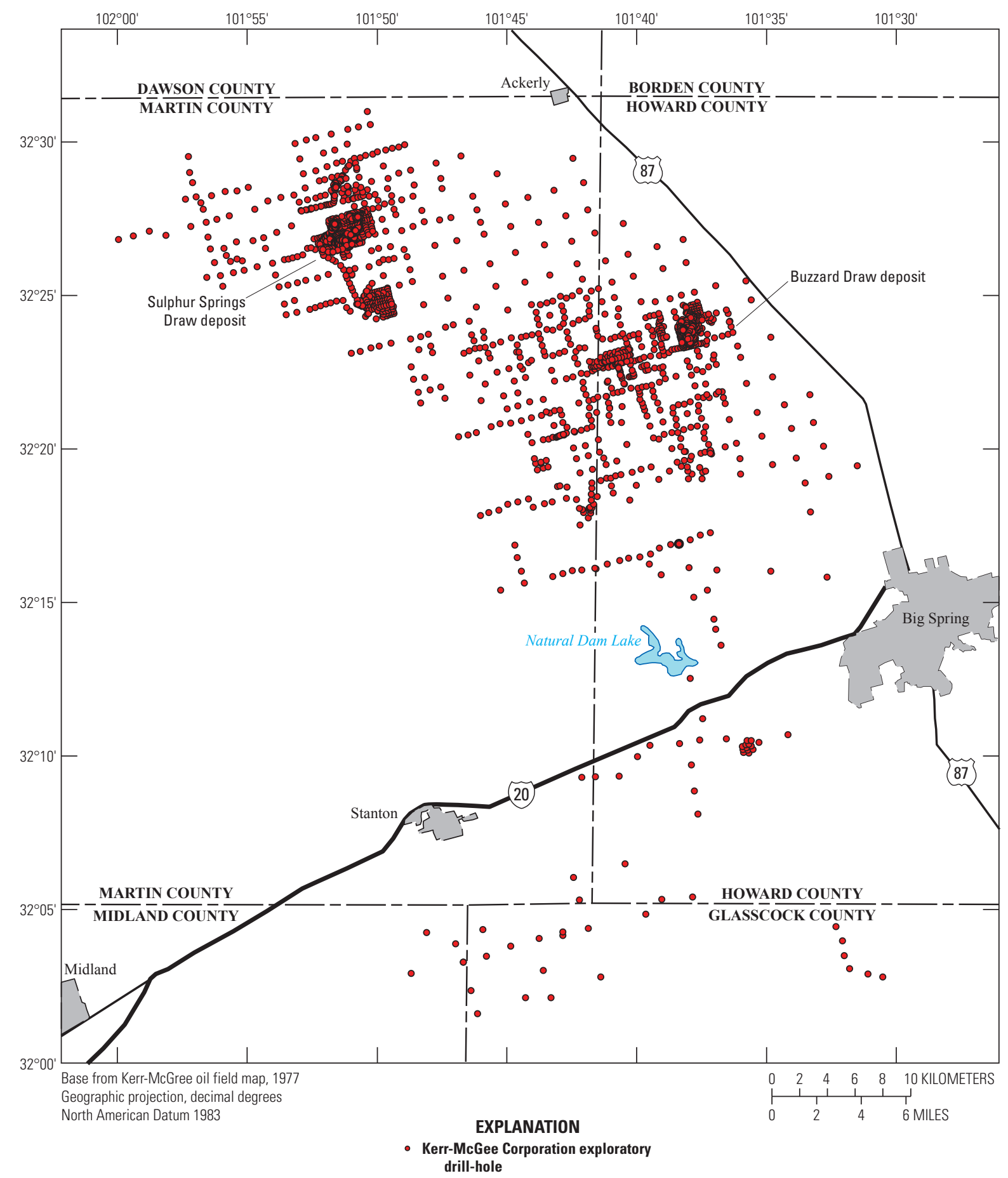

Figure 12. Drill-hole locations (red dots) of Kerr-McGee Corporation's 1970s exploratory drilling program in the Southern High Plains region of Texas. 


\section{Discussion}

Because the Kerr-McGee records have been well archived, the public is now aware of two near-surface uranium deposits within the Southern High Plains of west Texas. These deposits are calcrete uranium deposits, a deposit type not previously reported in the United States. The west Texas deposits are smaller in size and of lower uranium grade than the classic calcrete uranium deposits of Yeelirrie in Western Australia (Carlisle, 1978; Butt and others, 1984; Cameron, 1984; Cavaney, 1984; Heath and others, 1984), and they differ in some details, but they do share several geologic similarities For example, the Pleistocene paleogeography and depositional environments of the Southern High Plains are generally similar to those in which the West Australia uranium deposits were formed. Also, they are similar in (1) the principal uranium ore mineral, carnotite; (2) the host rocks, calcareous lacustrine sediments (calcrete); (3) the climatic conditions during deposition, arid to semiarid; (4) the geographic setting, an inland setting with a low regional gradient; and (5) the depths to the ore zones, shallow (the deposits often occurring within 10-20 m of the ground surface).

The discovery of the west Texas deposits suggests that other uranium deposits of this type can exist in the Southern High Plains and could be concealed beneath the widespread cover of the Blackwater Formation. The discovery of additional deposits by Kerr-McGee's exploration project could have been limited by (1) the spacing of the airborne flight lines (exact flight line spacing is not known, but some deposits may not have been crossed by a flight line); (2) the shallow depth of penetration by airborne radiometric surveys (they cannot detect anomalous radioactivity beneath as little as $0.5 \mathrm{~m}$ of cover such as soil or loess); (3) the possibility of difficulties obtaining land access for follow-up ground surveys; and (4) a sparse distribution of water wells for chemical analyses in some areas.

Because a deposit model that explains the genesis of these uranium deposits could aid in the discovery of additional deposits in the region, one was developed as part of this study. This deposit model includes the characteristics, depositional setting, and age of the host calcrete strata; the source(s) of the uranium and vanadium; mechanism(s) of uranium-vanadium precipitation; and the age(s) of the uranium-vanadium mineralization.

\section{Host Calcrete Strata}

Several pieces of evidence suggest that the host strata for the uranium mineralization are sediments deposited in Pleistocene saline lakes. Micritic dolomite is the principal mineral, accompanied by considerable celestine $\left(\mathrm{SrSO}_{4}\right)$; these are common mineral precipitates in saline lakes. The bowl shape of the calcrete strata fits the typical morphology of deposits emplaced in a shallow lacustrine setting, which would be a few kilometers in diameter and filled with sediments as much as $30 \mathrm{~m}$ thick. The paleogeology, paleogeography, and paleoclimate of the Southern High Plains indicate that saline lakes existed in the region during interglacial periods of the Pleistocene, as represented by strata of the Pleistocene-age Tahoka Formation and extinct Pleistocene Lake Lomax, the basin of which is located about $10-20 \mathrm{~km}$ to the south of the uranium deposits (fig. 3) (Frye and Leonard, 1968). The age of the host calcrete at the Sulphur Springs Draw deposit is provisionally dated at about $190 \mathrm{ka}$, based on preliminary uranium-series dating of the unmineralized micritic dolomite matrix (Hall and others, 2016). However, the presence of the Lava Creek B ash layer $\left(631 \pm 4 \mathrm{ka},{ }^{40} \mathrm{Ar} /{ }^{39} \mathrm{Ar}\right.$ method, Fish Canyon standard, 28.17 Ma, Matthews and others, 2015) in strata immediately adjacent to the Sulphur Springs Draw deposit strongly suggests that strata of the Tule Formation host the uranium deposit. The $190 \mathrm{ka}$ age for the dolomite matrix may indicate a younger fluid event that recrystallized the host rocks.

\section{Sources and Mechanisms of the Uranium- Vanadium Mineralization}

The most expedient source of uranium and vanadium to these deposits is the Dockum Group strata that lie beneath and in direct contact with the calcrete strata. The Dockum Group in the region locally contains numerous uranium occurrences and small deposits (Hayes, 1956; Finch, 1975). For example, small uranium deposits occur in the Dockum Group in Garza County, about $100 \mathrm{~km}$ to the northeast of the Sulphur Springs Draw and Buzzard Draw deposits. The Dockum Group deposits contain uranium-vanadium mineralization in the form of tyuyamunite and metatyuyamunite.

In addition to the Dockum Group minerals, an ash bed now recognized in strata immediately adjacent to the Sulphur Springs Draw deposit offers another potential source of uranium. As described in the "Pleistocene Lacustrine Deposits that Host the Uranium Deposits" section, the USGS Tephrochronology Project determined that this ash was Lava Creek B with an age of $631 \pm 4 \mathrm{ka}\left({ }^{40} \mathrm{Ar} /{ }^{39} \mathrm{Ar}\right.$ method, Fish Canyon standard, 28.17 Ma, Matthews and others, 2015); thus, its eruptive source was from the Yellowstone National Park region of Wyoming. The Lava Creek B ash in this region occurs in the upper part of the Tule Formation (middle Pleistocene), suggesting that strata of the Tule Formation are the host for the Sulphur Springs Draw uranium deposit. Geochemical analyses of a hand sample of this ash-bearing layer found a uranium content of $6.9 \mathrm{ppm}$.

Other traditional sources of uranium and vanadium, such as igneous and metamorphic rocks, form the basement in the Southern High Plains and are covered by more than $2 \mathrm{~km}$ of sediment. The nearest surface exposures of basement rocks occur hundreds of kilometers from the uranium deposits.

Uranium-vanadium minerals may be the least soluble of uranyl minerals and are thought to most likely form when dissolved uranium comes in contact with waters containing dissolved vanadate ions (Finch and Murakami, 1999). Vanadium in reduced form is often found in clay-rich rocks (mudstones and shales). Most reported occurrences of carnotite are as oxidation products of reduced U(IV) minerals and 
associated reduced V(III)-bearing clays. Thus, the source of uranium and vanadium for the west Texas deposits (carnotitegroup minerals) may be the chemically reduced, greenishgray, clayey strata of the underlying Dockum Group. Upon oxidation of these strata, uranium and (or) vanadium can be mobilized upward from Dockum Group mudstones into the overlying Pleistocene sediments.

Elevated concentrations of uranium, and associated radioactive daughter products such as radon and radium, are common in shallow groundwaters of the Southern High Plains, particularly in saline lake basins, based on many analyses of well waters in the region (Bartolino, 1991; Hopkins, 1993; Hudak, 2005; Scanlon and others, 2009; Ranalli and Yager, 2016). Hudak (2005) collected 48 samples of well waters from the Dockum aquifer and found that 17 percent of the samples exceeded the drinking-water standards for alpha radioactivity. He concluded, "Uranium deposits in sandstone and shale of the Dockum aquifer, and in calcrete and silcrete of the Ogallala aquifer, and overlying lacustrine sediments, likely influence radioactivity patterns observed in this study" (Hudak, 2005, p. 283). Scanlon and others (2009) report that dissolved vanadium can also be anomalously high in saline groundwaters of the Southern High Plains aquifer.

Ranalli and Yager (2016) used the USGS computer software code PHREEQC (Parkhurst and Appelo, 1999) to model the potential for precipitation of carnotite from water that is sufficiently saturated in uranium and vanadium concentrations through progressive evaporation of groundwaters typical of the Southern High Plains. Some of the groundwaters were tapped by wells in the area of the uranium deposits. They input the chemistry of shallow groundwaters from wells in the Ogallala aquifer, systematically varied the concentration of uranium in groundwater, and modeled the progressive evaporation of the water while variably opening and closing the system to $\mathrm{CO}_{2}$. The calculations found that unusually high initial concentrations of total dissolved uranium and vanadium in the groundwater were not required to achieve carnotite saturation. Rather, "in groundwater that achieved carnotite saturation the [initial] concentration of uranium ranged from 2.12 to $21.9 \mu \mathrm{g} / \mathrm{L}$ with a median concentration of $9.14 \mu \mathrm{g} / \mathrm{L}$ and the concentration of vanadium ranged from 12.8 to $118 \mu \mathrm{g} / \mathrm{L}$ with a median concentration of $29.3 \mu \mathrm{g} / \mathrm{L}$ " (Ranalli and Yager, 2016, p. 130; $\mu \mathrm{g} / \mathrm{L}$, microgram per liter). Their calculations indicated that carnotite saturation could be achieved through the evaporation of a subset of groundwaters under three conditions: (1) the initial water chemistry was dominated by $\mathrm{Ca}-\mathrm{Mg}-\mathrm{SO}_{4}$ or $\mathrm{Ca}-\mathrm{Mg}$ bicarbonate; (2) the system was open to $\mathrm{CO}_{2}$; and (3) following the precipitation of calcite, the concentration of calcium exceeded carbonate alkalinity. These boundary conditions could have occurred within saline lakes in this region during the Pleistocene.

\section{Relative Ages of the Uranium-Vanadium Mineralization}

This study included mineralogical analyses of uraniumvanadium mineralization in outcrop samples taken from the trench exposure at the Sulphur Springs Draw deposit (Hall and others, 2016). The analyses used a scanning electron microscope equipped with energy-dispersive X-ray spectroscopy. In addition, six subsamples from two lacustrine calcrete specimens (one unmineralized and one with carnotite coating fracture surfaces) were analyzed for uranium-series isotopes by thermal ionization mass spectrometry. As noted in the "Sulphur Springs Draw Deposit" section, results imply that finely disseminated uranium mineralization in the fine-grained dolomite matrix formed prior to about $190 \mathrm{ka}$ and secondary uranium-vanadium mineralization was introduced much later (Holocene). Paragenetically early carnotite is disseminated in the dolomicrite host in small pores and is present as coatings on dolomite grains and on thin veinlets. Later-stage crusts composed of carnotite, a uranium-strontium-vanadium mineral, celestite, and a strontium-calcium carbonate were deposited in vuggy areas and on thin fracture surfaces. The paragenetically late crusts of a uranium-vanadium mineral (carnotite) and a uranium-strontium-vanadium mineral may have formed as recently as about $5 \mathrm{ka}$ based on interpretations of preliminary uranium-series dating. Differences in initial ${ }^{234} \mathrm{U} / 238 \mathrm{U}$ activity ratios for the older dolomicrite matrix and the younger uranium-vanadium crusts indicate two distinct fluid sources. These data imply that the host micritic dolomite may represent the deposition of carbonate in the saline lake sediments (or relatively soon thereafter) during marine-isotope stage 7 interglacial conditions. The much younger uranium-vanadium and uranium-vanadium-strontium mineralization that formed crusts could represent recent remobilization of older uranium and vanadium concentrates from underlying sediments and (or) a separate fluid influx that brought additional uranium and vanadium to the system.

\section{Conclusions}

Further consideration of these factors will produce a refined deposit model that can indicate the most favorable areas for calcrete uranium deposits similar to those at Sulphur Springs Draw and Buzzard Draw. Because the extensive cover of the Blackwater Draw Formation complicates the use of standard regional reconnaissance techniques, such as airborne radiometric surveys, a deposit model could aid in the search for potential uranium deposits. Given the preliminary deposit model discussed in this report, it is likely that areas defined as favorable by a refined deposit model will be along the margins of "draws" that incise the plains, as exemplified by KerrMcGee's two discoveries. 


\section{References Cited}

Barnes, V.E., Hartmann, B.M., and Scranton, D.F., 1992, Geologic map of Texas [Northwest quadrant]: University of Texas at Austin, Bureau of Economic Geology, scale 1:500,000.

Bartolino, J.R., 1991, Radon-222 in the groundwater surrounding the Anton Lake basin, Hockley County, Texas: Lubbock, Tex., Texas Tech University, Ph.D. dissertation, 209 p.

Brand, J.P., 1956a, Cretaceous system, in Eastern Llano Estacado and adjoining Osage Plains, Guidebook, 1956 spring fieldtrip, April 6-7, 1956: Lubbock, Tex., West Texas Geological Society and Lubbock Geological Society, p. $10-13$.

Brand, J.P., 1956b, Triassic system, in Eastern Llano Estacado and adjoining Osage Plains, Guidebook, 1956 spring fieldtrip, April 6-7, 1956: Lubbock, Tex., West Texas Geological Society and Lubbock Geological Society, p. 8-9.

Butt, C.R.M., Mann, A.W., and Horwitz, R.C., 1984, Regional setting, distribution and genesis of surficial uranium deposits in calcretes and associated sediments in Western Australia, in Surficial uranium deposits: International Atomic Energy Agency IAEA-TECDOC-322, p. 121-127.

Cameco Corporation, 2016, Measured and indicated resources: Cameco Corporation web page, accessed September 22, 2017, at http://www.cameco.com/invest/overview/ reserves-resources/measured-indicated.

Cameron, E., 1984, The Yeelirrie calcrete uranium deposit, Western Australia, in Surficial uranium deposits: International Atomic Energy Agency IAEA-TECDOC-322, p. 157-164.

Carlisle, Donald, 1978, The distribution of calcretes and gypcretes in southwestern United States and their uranium favorability-Based on a study of deposits in Western Australia and south west Africa (Namibia): U.S. Department of Energy Open-File GJBX-29(78), 274 p., 21 plates.

Cavaney, R.J., 1984, Lake Maitland uranium deposit, in Surficial uranium deposits: International Atomic Energy Agency IAEA-TECDOC-322, p. 137-140.

Eifler, G.K., Jr., Frye, J.C., and Leonard, A.B., 1974, Geologic atlas of Texas, Big Spring sheet: University of Texas at Austin, Bureau of Economic Geology, scale 1:250,000, 6-p. explanatory booklet.

Evans, G.L., 1956, Cenozoic geology, in Eastern Llano Estacado and adjoining Osage Plains, Guidebook, 1956 spring fieldtrip, April 6-7, 1956: Lubbock, Tex., West Texas Geological Society and Lubbock Geological Society, p. $15-26$.
Finch, Robert, and Murakami, Takashi, 1999, Systematics and paragenesis of uranium minerals, in Burns, P.C., and Finch, Robert, eds., Uranium-Mineralogy, geochemistry, and the environment: Washington, D.C., Mineralogical Society of America Reviews in Mineralogy, v. 38, p. 91-179.

Finch, W.I., 1975, Uranium in west Texas-Paper delivered June 3, 1975, AAPG-SEPM Rocky Mountain section meeting, Albuquerque, New Mexico: U.S. Geological Survey Open-File Report 75-356, 20 p.

Finch, W.I., 1991, Maps showing the distribution of uraniumdeposit clusters in the Colorado Plateau uranium province: U.S. Geological Survey Miscellaneous Field Studies Map MF-2080, scale 1:2,500,000.

Finch, W.I., Otton, J.K., and Pierson, C.T., 1995, Uranium and vanadium - Uranium deposits and occurrences, in Bartsch-Winkler, Susan, and Donatich, A.J., eds., Mineral and energy resources of the Roswell resource area, eastcentral New Mexico: U.S. Geological Survey Bulletin 2063, p. 110-114.

Frelier, A.P., 1987, Sedimentology, fluvial paleohydrology, and paleomorphology of the Dockum Formation (Triassic), Garza County, west Texas: Lubbock, Tex., Texas Tech University, M.S. thesis, 198 p.

Frye, J.C., and Leonard, A.B., 1957, Studies of Cenozoic geology along eastern margin of Texas High Plains, Armstrong to Howard Counties: University of Texas at Austin, Bureau of Economic Geology Report of Investigations No. 32, 62 p., 10 figs., 5 pl.

Frye, J.C., and Leonard, A.B., 1968, Late-Pleistocene Lake Lomax in western Texas, in Morrison, R.B., and Wright, H.E., eds., Means of correlation of Quaternary successions, v. 8 of Proceedings of the VII Congress of the International Association for Quaternary Research: Salt Lake City, Utah, University of Utah Press, p. 519-534.

Frye, J.C., Leonard, A.B., and Glass, H.D., 1982, Western extent of Ogallala Formation in New Mexico: New Mexico Bureau of Mines \& Mineral Resources Circular 175, 41 p.

Geodata International Inc., 1980, Aerial radiometric and magnetic survey, Big Spring national topographic map, Texas, west Texas project: U.S. Department of Energy Open-File Report GJBX-196(80).

Goolsby, J.E., 1975, Cenozoic stratigraphy and geomorphology of Lynn and Terry Counties, Texas: Lubbock, Tex., Texas Tech University, Ph.D. dissertation, 98 p.

Gustavson, T.C., 1996, Fluvial and eolian depositional systems, paleosols, and paleoclimate of the upper Cenozoic Ogallala and Blackwater Draw Formations, Southern High Plains, Texas and New Mexico: University of Texas at Austin, Bureau of Economic Geology Report of Investigations No. 239, 62 p., 42 figs., 2 tables, 4 oversize cross sections. 
Gustavson, T.C., and Finley, R.J., 1985, Late Cenozoic geomorphic evolution of the Texas Panhandle and northeastern New Mexico: University of Texas at Austin, Bureau of Economic Geology Report of Investigations No. 148, 43 p., 20 figs.

Gustavson, T.C., and Holliday, V.T., 1999, Eolian sedimentation and soil development on a semiarid to subhumid grassland, Tertiary Ogallala and Quaternary Blackwater Draw Formations, Texas and New Mexico High Plains: Journal of Sedimentary Research, v. 69, no. 3, p. 622-634.

Gustavson, T.C., Holliday, V.T., and Hovorka, S.D., 1995, Origin and development of playa basins, sources of recharge to the Ogallala aquifer, Southern High Plains, Texas and New Mexico: The University of Texas at Austin, Bureau of Economic Geology, Report of Investigations No. 229, 44 p., 22 figs., 4 tables.

Gustavson, T.C., and Winkler, D.A., 1988, Depositional facies of the Miocene-Pliocene Ogallala Formation, northwestern Texas and eastern New Mexico: Geology, v. 16, no. 3, p. 203-206.

Hall, S.A., 2001, Geochronology and paleoenvironments of the glacial-age Tahoka Formation, Texas and New Mexico High Plains: New Mexico Geology, v. 23, no. 3, p. 71-77.

Hall, S.M., Paces, J.B., and Van Gosen, B.S., 2016, Mineralogy and paragenesis of the Sulphur Springs Draw calcretetype uranium deposit, northern Texas, in Geological Society of America Annual Meeting, Denver, Colo., September 25-28, 2016: Geological Society of America Abstracts with Programs, v. 48, no. 7, accessed September 22, 2017, at https://gsa.confex.com/gsa/2016AM/webprogram/ Paper281613.html.

Hayes, W.C., 1956, Uranium prospects in west Texas, in Eastern Llano Estacado and adjoining Osage Plains, Guidebook, 1956 spring fieldtrip, April 6-7, 1956: Lubbock, Tex.,West Texas Geological Society and Lubbock Geological Society, p. 69-72.

Heath, A.G., Deutscher, R.L., and Butt, C.R.M., 1984, Lake Austin uranium deposit, Western Australia, in Surficial uranium deposits: International Atomic Energy Agency IAEA-TECDOC-322, p. 129-132.

Hill, P.L., Kucks, R.P., and Ravat, Dhananjay, 2009, Aeromagnetic and aeroradiometric data for conterminous United States and Alaska from the National Uranium Resource Evaluation (NURE) Program of the U.S. Department of Energy: U.S. Geological Survey Open-File Report 20091129, accessed September 22, 2017, at https://pubs.er.usgs. gov/publication/ofr20091129.

Holliday, V.T., 1988, Mount Blanco revisited-Soilgeomorphic implications for the ages of the upper Cenozoic Blanco and Blackwater Draw Formations: Geology, v. 16, no. 6, p. 505-508.
Holliday, V.T., 1989, The Blackwater Draw Formation (Quaternary) - A 1.4-plus-m.y. record of eolian sedimentation and soil formation on the Southern High Plains: Geological Society of America Bulletin, v. 101, no. 12, p. 1598-1607.

Holliday, V.T., 1990, Sedimentation, soil stratigraphy, and age of the Blackwater Draw Formation, in Gustavson, T.C., ed., Geologic framework and regional hydrology-Upper Cenezoic Blackwater Draw and Ogallala Formations, Great Plains: Austin, Tex., The University of Texas at Austin, Bureau of Economic Geology, p. 10-22.

Holliday, V.T., 1995, Stratigraphy and paleoenvironments of late Quaternary valley fills on the Southern High Plains: Geological Society of America Memoir 186, 136 p.

Hopkins, Janie, 1993, Water-quality evaluation of the Ogallala aquifer, Texas: Texas Water Development Board Report $342,41 \mathrm{p}$.

Hudak, P.F., 2005, Radioactivity in the Ogallala and Dockum aquifers, northwest Texas, USA: Environmental Geology, v. 47, no. 2, p. 283-289.

Matthews, N.E., Vazquez, J.A., and Calvert, A.T., 2015, Age of the Lava Creek supereruption and magma chamber assembly at Yellowstone based on ${ }^{40} \mathrm{Ar} /{ }^{39} \mathrm{Ar}$ and $\mathrm{U}-\mathrm{Pb}$ dating of sanidine and zircon crystals: Geochemistry, Geophysics, Geosystems, v. 16, no. 8, p. 2508-2528.

May, B.A., 1988, Depositional environments, sedimentology, and stratigraphy of the Dockum Group (Triassic) in the Texas Panhandle: Lubbock, Tex., Texas Tech University, M.S. thesis, $180 \mathrm{p}$.

McGowen, J.H., Granata, G.E., and Seni, S.J., 1977, Depositional systems, uranium occurrence and postulated ground-water history of the Triassic Dockum Group, Texas Panhandle-eastern New Mexico: Report prepared for the U.S. Geological Survey under Grant Number 14-08-0001G410, $104 \mathrm{p}$.

McGowen, J.H., Granata, G.E., and Seni, S.J., 1979, Depositional framework of the lower Dockum Group (Triassic) Texas Panhandle: University of Texas at Austin, Bureau of Economic Geology, Report of Investigations No. 97, 60 p., 43 figs., 2 tables.

McGowen, J.H., Seni, S.J., Anderson, R.L., and Thurwachter, J.E., 1981, National uranium resource evaluation, Lubbock quadrangle, Texas: U.S. Department of Energy, Open-File Report GJQ-012(81), 48 p.

Mullican, W.F., III, Johns, N.D., and Fryar, A.E., 1997, Playas and recharge of the Ogallala aquifer on the Southern High Plains of Texas-An examination using numerical techniques: University of Texas at Austin, Bureau of Economic Geology, Report of Investigations No. 242, 72 p., 29 figs., 9 tables. 
Murry, P.A., 1989, Geology and paleontology of the Dockum Formation (upper Triassic), west Texas and eastern New Mexico, in Lucas, S.G., and Hunt, A.P., eds., Dawn of the age of dinosaurs in the American Southwest: Albuquerque, N. Mex., New Mexico Museum of Natural History, p. 102-144.

Nativ, Ronit, 1988, Hydrogeology and hydrochemistry of the Ogallala aquifer, Southern High Plains, Texas Panhandle and eastern New Mexico: The University of Texas at Austin, Bureau of Economic Geology, Report of Investigations No. 177, 64 p., 35 figs., 1 table.

Otton, J.K., 1984, Surficial uranium deposits in the United States of America, in Surficial uranium deposits: International Atomic Energy Agency IAEA-TECDOC-322, p. 237-242.

Parkhurst, D.L., and Appelo, C.A.J., 1999, User's guide to PHREEQC (Version 2) - A computer program for speciation, batch-reaction, one-dimensional transport, and inverse geochemical calculations: U.S. Geological Survey WaterResources Investigations Report 99-4259, 312 p.

Ranalli, A.J., and Yager, D.B., 2016, Use of mineral/solution equilibrium calculations to assess the potential for carnotite precipitation from groundwater in the Texas Panhandle, USA: Applied Geochemistry, v. 73, p. 118-131.

Reeves, C.C., Jr., 1972, Tertiary-Quaternary stratigraphy and geomorphology of west Texas and southeastern New Mexico, in Kelly, V.C., and Trauger, F.D., eds., Guidebook of east-central New Mexico, New Mexico Geological Society Twenty-third Field Conference, September 28-30, 1972: New Mexico Geological Society, p. 108-117.

Reeves, C.C., Jr., 1976, Caliche-Origin, classification, morphology and uses: Lubbock, Tex., Estacado Books, 233 p.

Reeves, C.C., and Reeves, J.A., 1996, The Ogallala aquifer of the Southern High Plains: Lubbock, Tex., Estacado Books, $360 \mathrm{p}$.

Rich, Julie, 2013, A 250,000-year record of lunette dune accumulation on the Southern High Plains, USA and implications for past climates: Quaternary Science Reviews, v. 62 , p. $1-20$.

Scanlon, B.R., Goldsmith, R.S., Hovorka, S.D., Mullican, W.F., III, and Xiang, J., 1994, Evidence for focused recharge beneath playas in the Southern High Plains, Texas, in Urban, L.V., and Wyatt, A.W., eds., Proceedings of the Playa Basin Symposium: Lubbock, Tex., Texas Tech University, p. 87-95.

Scanlon, B.R., Nicot, J.P., Reedy, R.C., Kurtzman, D., Mukherjee, A., and Nordstrom, D.K., 2009, Elevated naturally occurring arsenic in a semiarid oxidizing system, Southern High Plains aquifer, Texas, USA: Applied Geochemistry, v. 24, no. 11, p. 2061-2071.
Schultz, G.E., 1986, Biostratigraphy and volcanic ash deposits of the Tule Formation, Briscoe County, Texas, in Gustavson, T.C., ed., Geomorphology and Quaternary stratigraphy of the Rolling Plains, Texas Panhandle: University of Texas at Austin, Bureau of Economic Geology Guidebook, v. 22, p. $82-84$.

Texas Department of Water Resources, 1980, Playa lake monitoring for the Llano Estacado total water management study - Texas, Oklahoma, New Mexico, Colorado, and Kansas: Texas Department of Water Resources report LP-114, 18 p.

Winkler, D.A., 1985, Stratigraphy, vertebrae paleontology and depositional history of the Ogallala Group in Blanco and Yellowhouse canyons, northwestern Texas: Austin, Tex., University of Texas, Ph.D. dissertation, 243 p., 2 pl., 52 figs., 13 tables.

Winn, Rusty, 2015, Geological analysis of aggregates processing: Mining Engineering, v. 67, no. 2, p. 15-18.

Wood, H.B., 1968, Geology and exploitation of uranium deposits in the Lisbon Valley area, Utah, in Ridge, J.D., ed., Ore deposits of the United States, 1933-1967-The GratonSales volume: New York, N.Y., The American Institute of Mining, Metallurgical, and Petroleum Engineers, v. 1, p. $770-789$.

Wood, W.W., 2002, Role of ground water in geomorphology, geology, and paleoclimate of the Southern High Plains, USA: Groundwater, v. 40, no. 4, p. 438-447.

Wood, W.W., and Osterkamp, W.R., 1984, Playa lake basins on the Southern High Plains of Texas, U.S.A., a hypothesis for their development, in Proceedings of the Ogallala Aquifer Symposium II: Lubbock, Tex., Texas Tech University Water Resources Center, p. 304-311.

Wood, W.W., and Sanford, W.E., 1995, Chemical and isotopic methods for quantifying ground-water recharge in a regional, semiarid environment: Groundwater, v. 33, no. 3, p. $458-468$.

Publishing support provided by Denver Publishing Service Center

For more information concerning this publication, contact

Center Director, USGS Central Mineral and Environmental Resources Science Center

Box 25046, Mail Stop 973

Denver, CO 80225

(303) 236-1800

Or visit the Central Mineral and Environmental Resources Science Center website at https://minerals.cr.usgs.gov/ 
